\title{
Anti-Inflammatory Effects of Hyperbaric Oxygenation during DSS-Induced Colitis in BALB/c Mice Include Changes in Gene Expression of HIF-1 $\alpha$, Proinflammatory Cytokines, and Antioxidative Enzymes
}

\author{
Sanja Novak, ${ }^{1}$ Ines Drenjancevic, ${ }^{1}$ Rosemary Vukovic, ${ }^{2}$ Zoltán Kellermayer, ${ }^{3,4}$ Anita Cosic, ${ }^{1}$ \\ Maja Tolusic Levak, ${ }^{5}$ Péter Balogh, ${ }^{3,4}$ Filip Culo, ${ }^{1}$ and Martina Mihalj ${ }^{1}$ \\ ${ }^{1}$ Department of Physiology and Immunology, Faculty of Medicine, University of Osijek, 31000 Osijek, Croatia \\ ${ }^{2}$ Department of Biology, University of Osijek, 31000 Osijek, Croatia \\ ${ }^{3}$ Department of Immunology and Biotechnology, Faculty of Medicine, University of Pécs, 7624 Pécs, Hungary \\ ${ }^{4}$ Lymphoid Organogenesis Research Group, Szentágothai Research Center, University of Pécs, 7624 Pécs, Hungary \\ ${ }^{5}$ Department of Histology and Embryology, Faculty of Medicine, University of Osijek, 31000 Osijek, Croatia \\ Correspondence should be addressed to Martina Mihalj; martina.mihalj@mefos.hr
}

Received 25 March 2016; Revised 8 July 2016; Accepted 12 July 2016

Academic Editor: Fábio Santos Lira

Copyright (C) 2016 Sanja Novak et al. This is an open access article distributed under the Creative Commons Attribution License, which permits unrestricted use, distribution, and reproduction in any medium, provided the original work is properly cited.

\begin{abstract}
Reactive oxygen species (ROS) and nitrogen species have an indispensable role in regulating cell signalling pathways, including transcriptional control via hypoxia inducible factor- $1 \alpha(\mathrm{HIF}-1 \alpha)$. Hyperbaric oxygenation treatment $\left(\mathrm{HBO}_{2}\right)$ increases tissue oxygen content and leads to enhanced ROS production. In the present study DSS-induced colitis has been employed in BALB/c mice as an experimental model of gut mucosa inflammation to investigate the effects of $\mathrm{HBO}_{2}$ on $\mathrm{HIF}-1 \alpha$, antioxidative enzyme, and proinflammatory cytokine genes during the colonic inflammation. Here we report that $\mathrm{HBO}_{2}$ significantly reduces severity of DSSinduced colitis, as evidenced by the clinical features, histological assessment, impaired immune cell expansion and mobilization, and reversal of $I L-1 \beta, I L-2$, and $I L-6$ gene expression. Gene expression and antioxidative enzyme activity were changed by the $\mathrm{HBO}_{2}$ and the inflammatory microenvironment in the gut mucosa. Strong correlation of HIF-1 $\alpha$ mRNA level to GPx1, SOD1, and IL-6 mRNA expression suggests involvement of HIF-1 $\alpha$ in transcriptional regulation of these genes during colonic inflammation and $\mathrm{HBO}_{2}$. This is further confirmed by a strong correlation of HIF- $1 \alpha$ with known target genes VEGF and PGK1. Results demonstrate that $\mathrm{HBO}_{2}$ has an anti-inflammatory effect in DSS-induced colitis in mice, and this effect is at least partly dependent on expression of $H I F-1 \alpha$ and antioxidative genes.
\end{abstract}

\section{Introduction}

Relapsing chronic inflammation found in the gut of individuals affected by inflammatory bowel diseases (IBD) is a result of several overlapping factors, including dysregulation of the immune response to the enteric microbiota, genetic susceptibility, and environmental factors [1, 2]. Reactive oxygen (ROS) and nitrogen (RNS) species generated by inflammatory cells during an immune response create oxidative stress and are considered as important factors contributing to the pathogenesis of IBD. Lymphocytes, neutrophils, and macrophages activated during the gut inflammation produce high amounts of ROS/RNS destroying surrounding tissue [3]. Although oxidative stress is a major factor in the inflamed tissue leading towards necrosis, DNA damage, and carcinogenesis, certain amounts of ROS and other free radicals have an indispensable role in regulating different cell signalling pathways [4]. In addition, some immune cells, namely, the macrophages and neutrophils, use ROS to combat the microorganisms responsible for the infection. 
Current therapies of IBD, including immunosuppressive drugs, antibiotics, and biological drugs, are efficient in controlling the course of the disease. However, for many affected individuals, conventional therapy becomes an inadequate choice for long-term treatment because of significant side effects and risk factors, such as increased cancer risk, development of tuberculosis, and heart failure [5-7]. In recent years, hyperbaric oxygen $\left(\mathrm{HBO}_{2}\right)$ therapy has been introduced as a possible additional treatment for IBD patients, especially in the case of refractory disease when the standard therapy is ineffective.

$\mathrm{HBO}_{2}$ involves exposure to $100 \%$ oxygen under pressure greater than 1 atmosphere of absolute pressure (ATM). It is a well-established procedure frequently applied in the medical practice, especially effective in treating wounds of various aetiologies [8-11]. $\mathrm{HBO}_{2}$ increases blood and tissue oxygen saturation resulting also in enhanced production of ROS and RNS [12]. Previous studies have verified that the clinical efficacy of $\mathrm{HBO}_{2}$ derives from modulation of intracellular transduction cascades, leading to synthesis of growth factors which promote wound healing, neoangiogenesis, and ameliorates postischemic and postinflammatory injuries [13]. Additional investigations on the mechanism underlying $\mathrm{HBO}_{2}$-induced wound healing have revealed a central role of hypoxia inducible factor-1 alpha (HIF-1 $\alpha$ ) as transcriptional regulator of genes involved in angiogenesis, energy metabolism, and cell proliferation $[9,14$, 15]. A further important function attributed to the HIF$1 \alpha$ is modulation of the immune responses, including the helper T-cell differentiation towards regulatory (Treg) versus Th17 phenotype $[16,17]$ and its strong anti-inflammatory activity in the gastrointestinal mucosa and hypoxic epithelium as a result of the transactivation of specific genes encoding for barrier-protective elements such as mucins $[18-20]$.

Hypoxia and ROS/RNS can induce stabilization of HIF-1 $\alpha$ leading to the activation of the hypoxia signal transduction pathway [21]. Increased oxidative stress in the gut mucosa has been verified in humans suffering from ulcerative colitis $[22,23]$, as well as in experimentally induced colitis in animals $[24,25]$. A recent study revealed increased activity of antioxidative enzymes and reduced oxidative stress in the inflamed gut mucosa following $\mathrm{HBO}_{2}$ exposure [24]; however, specific mechanisms inducing activation of antioxidative enzymes in the inflamed colonic tissue upon $\mathrm{HBO}_{2}$ remain unknown.

Since there is evidence that the intracellular redox status is in a close correlation with the inflammatory microenvironment, and it can also be changed by $\mathrm{HBO}_{2}$, the aim of this study was to investigate the effects of $\mathrm{HBO}_{2}$ on the mRNA expression of HIF-1 $\alpha$, proinflammatory cytokines, and antioxidative enzymes in the gut and peripheral lymphoid organs of BALB/c mice with DSS-induced colitis. An additional aim was to assess the activity of antioxidative enzymes and whether HIF-1 $\alpha$ gene expression regulation during the gut inflammation and $\mathrm{HBO}_{2}$ treatment correlates with the changes in antioxidative and proinflammatory gene expression. Our findings reveal that $\mathrm{HBO}_{2}$ treatment may effectively modulate the intestinal milieu in inflammatory conditions involving HIF-1 $\alpha$-mediated regulation of antioxidative gene expression.

\section{Materials and Methods}

2.1. Animals. $\mathrm{BALB} / \mathrm{c}$ mice, obtained from Charles River (Calco, Italy), were bred at the animal facility of the Medical Faculty Osijek (Croatia). Mice were provided with standard rodent chow (Mucedola, Settimo Milanese, Italy) and water ad libitum. The experimental facility was maintained at $22 \pm 2^{\circ} \mathrm{C}, 55 \pm 5 \%$ humidity, and 12-hour light/dark cycle. All procedures involving live animals were conducted in accordance with the European Guidelines for the Care and Use of Laboratory Animals (directive 86/609/EEC) and were approved by the local Ethical Committee (Faculty of Medicine, University of Osijek) and Croatian Ministry of Agriculture.

2.2. Experimental Design. For each experiment male mice at the age of 10-12 weeks were randomized into 4 groups ( $n=4-5 \mathrm{mice} /$ group/experiment): control mice (CTRL), control mice undergoing $\mathrm{HBO}_{2}\left(\mathrm{CTRL}+\mathrm{HBO}_{2}\right)$, mice receiving dextran sodium sulphate (DSS), and DSS treated mice undergoing $\mathrm{HBO}_{2}$ (DSS $+\mathrm{HBO}_{2}$ ). The average body weight of the mice at the time of inclusion into the study was $22.8 \pm 0.4 \mathrm{~g}$. Colitis was induced by $5 \%(\mathrm{w} / \mathrm{v})$ of DSS (Mr 36.000-50.000, MP Biomedicals, Illkrich, France) in drinking water ad libitum for 7 consecutive days [26, 27]. The $\mathrm{HBO}_{2}$ treatment was initiated at day 1 and was administered twice a day, 12 hours apart, until the end of experiment (the last session was applied in the morning of day $8 ; 15$ sessions in total). During one $\mathrm{HBO}_{2}$ session, mice were exposed to $100 \% \mathrm{O}_{2}$ for 60 minutes at 2.4 bars with addition of 15 minutes for gradual compression and decompression. Mice were sacrificed by cervical dislocation on day 8 , after the morning $\mathrm{HBO}_{2}$ session. Disease activity index (DAI) was assessed by daily measurement and scoring of animal body weight loss, stool consistency, and the presence of occult or gross blood per rectum. Measurements were performed at the same time each day until the end of experiment (day 8). DAI was determined as a sum of body weight loss score (0, none; $1,1-5 \%$ loss; $2,5-10 \% ; 3,10-15 \%$; $4,>15 \%$ ), stool consistency score (0, normal; 2, loose stool; 4, diarrhea), and score of occult/gross bleeding ( 0 , normal; 2 , occult bleeding; 4, gross hematochezia). Mice were sacrificed by cervical dislocation on day 8 following the last morning $\mathrm{HBO}_{2}$ treatment. Colons, mesenteric lymph nodes (MLN), and spleens were collected for further analysis. Colon length was determined for each animal.

2.3. Histological Assessment of Colitis. Colonic tissue was removed immediately after the animals were sacrificed, washed in PBS, and fixed in $4 \%$ paraformaldehyde. After 72 hours fixed tissue was embedded in paraffin and cut into a series of $6 \mu \mathrm{m}$ thick sections. Slides were dried, deparaffinised, rehydrated, and stained with haematoxylin and eosin. Histological disease activity was assessed by an experienced histologist, blinded for clinical information. 
Histological evaluation was preformed according to modified Geboes score as follows [28]:

Grade 0 (structural (architectural changes)):

0 : no abnormality,

1: mild abnormality,

2: mild or moderate diffuse or multifocal abnormalities,

3: severe diffuse or multifocal abnormalities.

Grade 1 (chronic inflammatory infiltrate):

0: no increase,

1: mild but unequivocal increase,

2: moderate increase,

3: marked increase.

Grade 2 (lamina propria leukocytes):

0 : no increase,

1: mild but unequivocal increase,

2: moderate increase,

3: marked increase.

Grade 3 (intraepithelial neutrophils):

0 : none,

1: $<5 \%$ crypts involved,

$2:<50 \%$ crypts involved,

3: $>50 \%$ crypts involved.

Grade 4 (crypt destruction):

0 : none,

1: probable, local excess of neutrophils in part of crypt,

2: probable, marked attenuation.

Grade 0 (structural (architectural changes)):

3: unequivocal crypt destruction.

Grade 5 (erosion or ulceration):

0: no erosion, ulceration, or granulation tissue,

1: recovering epithelium + adjacent inflammation,

2: probable erosion focally stripped,

3: unequivocal erosion,

4: ulcer or granulation tissue.

Slides were analysed using light microscopy at magnifications 40x, 100x, 200x, and 400x and photographed at 200x (Olympus ${ }^{\circledR}$ BX50 microscope, Olympus C-5050 digital camera, and QuickPHOTO PRO imaging software (Promicra s.r.o., Prague, Czech Republic)).
2.4. Isolation of Lamina Propria Lymphocytes. After isolation, the colon was cleaned of intestinal content and freed of fat tissue, washed in DMEM (Sigma Aldrich, Steinheim, Germany), cut into $5 \mathrm{~cm}$ long pieces, and, while shaken at $100 \mathrm{rpm}$, incubated at $37^{\circ} \mathrm{C}$ for 20 minutes in DMEM with $25 \mathrm{mM}$ EDTA. The tissue was then thoroughly washed in PBS buffer for at least 5 times, cut into $2 \mathrm{~mm}$ long strips, and digested in DMEM containing $5 \mathrm{U} / \mathrm{mL}$ DNase (Roche, Mannheim, Germany) and collagenase II (Gibco, Paisley, $\mathrm{UK})$ at $37^{\circ} \mathrm{C}$ for $20 \mathrm{~min}$. Following this, supernatant was removed, and the previous step was repeated until complete digestion of the tissue was achieved. The supernatant was then filtered through a $100 \mu \mathrm{m}$ sized filter; DMEM $+2 \%$ FBS (Sigma Aldrich, Steinheim, Germany) was added and centrifuged at $800 \times \mathrm{g}$ for $10 \mathrm{~min}$ at room temperature. Cells were resuspended in $5 \mathrm{~mL}$ of $40 \%$ Percoll (GE Healthcare, Uppsala, UK), overlaid on $4 \mathrm{~mL}$ of $80 \%$ Percoll, and centrifuged at $900 \times \mathrm{g} / 20 \mathrm{~min} / 4^{\circ} \mathrm{C}$. Lymphocytes from the interphase were collected and analysed by flow cytometry.

2.5. Flow Cytometry. Lymphocytes were isolated from the mesenteric lymph nodes (MLN) and spleen by teasing apart the organs between the frosted ends of two microscopic slides. The cells were incubated with a mixture of PE anti-CD4 (clone GK1.5, ExBio antibodies), FITC antiB220 (clone RA3-6B2, obtained from the American Type Culture Collection and conjugated with FITC using standard procedures), and APC anti-CD3 antibodies (clone 145-2C11, ExBio antibodies) and the other panel with PerCP antiCD45 (clone 30-F11, BD Biosciences), FITC anti-Gr-1 (clone RB6-8C5, BD Biosciences), and PE anti-F4/80 (clone BM8, StemCell Technologies Inc.) or PE anti-CD4 (clone MEM241, ExBio antibodies) and PerCP anti-CD8 (clone MEM-31, ExBio antibodies) antibodies. Dead cells were excluded based on 7-aminoactinomycin D (7-AAD) (Applichem, Darmstadt, Germany) staining. At least 20,000 live cells were collected by a BD FACS Canto II cytometer (FACS Canto II, Becton Dickinson, San Jose, CA, USA) and analysed using the FlowLogic software (Inivai Technologies, Mentone, Australia).

2.6. Measurement of Intracellular ROS Level. To assess hydrogen peroxide $\left(\mathrm{H}_{2} \mathrm{O}_{2}\right)$ and peroxynitrite $\left(\mathrm{ONOO}^{-}\right)$level, $10^{6}$ lymphocytes isolated from MLN and spleens were incubated for $30 \mathrm{~min}$ on $+4^{\circ} \mathrm{C}$ with $10 \mu \mathrm{M}$ dichlorofluorescein diacetate (DCF-DA) (Biomol, Hamburg, Germany), washed for $5 \mathrm{~min}$ at $400 \times \mathrm{g}$ on $+4^{\circ} \mathrm{C}$, and analysed with the FACS Canto II. Following this, cells were stimulated with $100 \mathrm{nM}$ phorbol 12-myristate 13-acetate (PMA, Calbiochem, Darmstadt, Germany), incubated for $30 \mathrm{~min}$, and analysed for the second time. At each measurement minimum of 10,000 target cells were analysed. Data are expressed as the median fluorescence intensity $(\mathrm{MFI}) \pm$ s.e.m.

2.7. Real-Time PCR. Colon, MLN, and spleen samples were isolated, snap frozen in liquid nitrogen, and stored at $-80^{\circ} \mathrm{C}$ till analysis. Total RNA was extracted using ONE STEP RNA Reagent (BIO BASIC Inc., Markham, Ontario, Canada) 
TABLE 1: Primer sequences, PCR product length, and primers annealing temperature used for qPCR analysis.

\begin{tabular}{|c|c|c|c|c|}
\hline Gene & & Sequence & PCR product length/bp & Annealing temperature $/{ }^{\circ} \mathrm{C}$ \\
\hline \multirow{2}{*}{$H I F-1 \alpha$} & For & TGACGGCGACATGGTTTACA & \multirow{2}{*}{280} & \multirow{2}{*}{63} \\
\hline & Rev & AATATGGCCCGTGCAGTGAA & & \\
\hline \multirow{2}{*}{ SOD1 } & For & GGAAGCATGGCGATGAAAGC & \multirow{2}{*}{80} & \multirow{2}{*}{56} \\
\hline & Rev & GCCTTCTGCTCGAAGTGGAT & & \\
\hline \multirow{2}{*}{$G P x 1$} & For & TCCAGTATGTGTGCTGCTCG & \multirow{2}{*}{249} & \multirow{2}{*}{63} \\
\hline & Rev & GTGTCCGAACTGATTGCACG & & \\
\hline \multirow{2}{*}{ CAT } & For & GGTGCCCCCAACTATTACCC & \multirow{2}{*}{141} & \multirow{2}{*}{61} \\
\hline & Rev & GAATGTCCGCACCTGAGTGA & & \\
\hline \multirow{2}{*}{$I L-1 \beta$} & For & GCCTTGGGCCTCAAAGGAAAGAATC & \multirow{2}{*}{282} & \multirow{2}{*}{66} \\
\hline & Rev & GGAAGACACAGATTCCATGGTGAAG & & \\
\hline \multirow{2}{*}{$I L-2$} & For & CTCTGCGGCATGTTCTGGAT & \multirow{2}{*}{163} & \multirow{2}{*}{65} \\
\hline & Rev & AGAAAGTCCACCACAGTTGCT & & \\
\hline \multirow{2}{*}{$I L-6$} & For & GCTGGAGTCACAGAAGGAGTGGC & \multirow{2}{*}{117} & \multirow{2}{*}{63} \\
\hline & Rev & GGCATAACGCACTAGGTTTGCCG & & \\
\hline \multirow{2}{*}{ HPRT1 } & For & TCAGTCAACGGGGGACATAAA & \multirow{2}{*}{142} & \multirow{2}{*}{59} \\
\hline & Rev & GGGGCTGTACTGCTTAACCAG & & \\
\hline
\end{tabular}

according to manufacturer's protocol. RNA purity and concentration was assessed by NanoPhotometer ${ }^{\circledR}$ P-Class P33030 (Implen, Munich, Germany). In order to purify RNA from all polysaccharides, including DSS, an additional purification step using $8 \mathrm{M} \mathrm{LiCl}$ was performed [29], followed by the standard genomic DNA purification step using Deoxyribonuclease I kit (Sigma Aldrich, St Louis, MO, USA). One microgram of RNA was used for cDNA synthesis by High Capacity cDNA kit with RNase Inhibitor (Applied Biosystems, Foster City, CA, USA). Real-time PCR was performed on CFX96 system (Bio Rad, Singapore) to assess relative expression of catalase $(C A T)$, glutathione peroxidase $1(G P x 1)$, superoxide dismutase 1 (SOD1), HIF-1 $\alpha, I L-1 \beta, I L-2$, and $I L-6$. Gene expression was normalized to HPRT1 gene. Primers list is given in the supplementary data (Table 1). Except for the primers for $I L-6$ gene published by Jeong et al. [30], all other primers were custom made using Primer 3 software. Messenger RNA expression was determined using SsoFast EvaGreen Supermix (Bio Rad, Singapore). Data are presented as mean \pm s.e.m.

2.8. Antioxidative Enzymes Activity Measurement. Frozen tissue samples were homogenized with liquid nitrogen and weighed. Tissue powder was additionally homogenized in $100 \mathrm{mM}$ phosphate buffer solution ( $\mathrm{pH} 7.0$ ) containing $1 \mathrm{mM}$ EDTA $(1: 10, \mathrm{w} / \mathrm{v})$ using Ultra turrax T10 homogenizer (IKA, Staufen, Germany) while kept on ice. Tissue homogenates were sonicated for 30 seconds on ice in three 10 seconds intervals and then centrifuged at $20,000 \times$ g for 15 minutes at $4^{\circ} \mathrm{C}$. Supernatant was collected, aliquoted, and stored at $-80^{\circ} \mathrm{C}$ till analysis. CAT, GPx, and SOD enzyme activities were determined using a Lambda $25 \mathrm{UV}$-Vis spectrophotometer equipped with UV WinLab 6.0 software package (Perkin Elmer for the Better, Massachusetts, USA).

Catalase (EC 1.11.1.6) activity was estimated spectrophotometrically using $\mathrm{H}_{2} \mathrm{O}_{2}$ as a substrate [31]. The reaction mixture consisted of $10 \mathrm{mM} \mathrm{H}_{2} \mathrm{O}_{2}$ in $50 \mathrm{mM}$ phosphate buffer
$\mathrm{pH}$ 7.0. Changes in absorbance of the reaction mixture were measured at $240 \mathrm{~nm}$ during 2 minutes after the sample addition. One unit of activity corresponds to the loss of $1 \mu \mathrm{mol}$ of $\mathrm{H}_{2} \mathrm{O}_{2}$ per minute. CAT activity was calculated using molar extinction coefficient $\left(\varepsilon=0.04 \mathrm{mM} \mathrm{cm}^{-1}\right)$ and expressed as $\mathrm{U} \mathrm{mg}^{-1}$ protein.

To assess glutathione peroxidase (EC 1.11.1.9) activity a modified method described by Wendel [32] using $\mathrm{H}_{2} \mathrm{O}_{2}$ as a substrate was employed. GPx activity was determined indirectly by measuring the rate of NADPH oxidation to $\mathrm{NADP}+$, accompanied by a decrease in absorbance at $340 \mathrm{~nm}$. The assay mixture consisted of $50 \mathrm{mM}$ phosphate buffer with $0.4 \mathrm{mM}$ EDTA and $1 \mathrm{mM}$ sodium azide ( $\mathrm{pH} 7.0), 0.12 \mathrm{mM}$ NADPH, 3.2 units of GR, $1 \mathrm{mM}$ glutathione, and $0.0007 \%$ (w/w) $\mathrm{H}_{2} \mathrm{O}_{2}$ in a total volume of $1.55 \mathrm{~mL}$. One unit catalyses the oxidation by $\mathrm{H}_{2} \mathrm{O}_{2}$ of $1.0 \mu$ mole of reduced glutathione to oxidized glutathione per minute at $\mathrm{pH} 7.0$ and $25^{\circ} \mathrm{C}$. GPx activity was calculated using molar extinction coefficient for NADPH $\left(\varepsilon=6.220 \mathrm{mMcm}^{-1}\right)$ and expressed as $\mathrm{U} \mathrm{mg}^{-1}$ protein.

Superoxide dismutase (EC 1.15.1.1.) activity was determined using cytochrome $\mathrm{C}(0.05 \mathrm{mM})$ as an inhibitory molecule in PBS buffer saline with $0.1 \mathrm{mM}$ EDTA in system xanthine $(1 \mathrm{mM})$ /xanthine oxidase $(50 \mathrm{U})$ by Flohe method [33].

Total soluble protein concentration in protein extracts was determined by Bradford reagent (Sigma Aldrich, Steinheim, Germany) following manufacturer's protocol and using bovine serum albumin as a standard.

2.9. Statistical Analysis. Normal distribution was assessed by the Shapiro Wilk test. Within groups differences were tested by one-way ANOVA or Kruskal-Wallis test followed by the Holm-Sidak/Tukey or Dunn's post hoc multiple comparison procedure, respectively (Sigma plot 11.0, SigmaStat Inc., San Jose, CA, USA). In some cases, the Student $t$-test and MannWhitney $U$ Statistic were used to compare the differences 
between the two groups in the case of normally distributed variables and variables that violated assumption of normality, respectively. Spearman's correlations were calculated where appropriate (Sigma plot 11.0, SigmaStat Inc.). DAI results were analysed by two-way ANOVA and Bonferroni post hoc test (GraphPad Prism 5.0, GraphPad Software, Inc., La Jolla, CA, USA). A $P$ value of $<0.05$ was considered statistically significant for all procedures. All data are presented as mean values \pm standard error of mean (s.e.m.).

\section{Results}

3.1. $\mathrm{HBO}_{2}$ Ameliorates the Course of DSS-Induced Colitis. In order to determine the effects of $\mathrm{HBO}_{2}$ on the course of acute colitis, BALB/c mice were exposed to 5\% DSS in the drinking water ad libitum and daily monitored for body weight, stool consistency, and occult/gross rectal bleeding to calculate DAI. In this study the DSS treatment induced substantial weight loss, rectal bleeding, loose stool, and colon shortening resulting in significantly higher DAI compared to the control (CTRL) group, starting from day 3 until the end of the experiment $(P<0.01$; Figure $1(\mathrm{a}))$. Mice that received DSS and underwent $\mathrm{HBO}_{2}$ treatment (DSS $+\mathrm{HBO}_{2}$ group) also presented with significantly higher DAI compared to the CTRL group; however, in this group of mice $\mathrm{HBO}_{2}$ treatment significantly reduced DAI compared to the DSS mice, starting from day 5 throughout day 8 (days 5 and $8 P<0.01$; days 6 and $7 P<0.05$; Figure 1(a)). In addition, average colon length in the DSS group of mice was significantly shorter $(8.14 \pm 0.23 \mathrm{~cm})$ compared to the CTRL group $(13.88 \pm$ $0.45 \mathrm{~cm} ; P<0.0001)$, while this effect was significantly ameliorated by $\mathrm{HBO}_{2}$ treatment in the DSS $+\mathrm{HBO}_{2}$ group $(11.34 \pm 0.38 \mathrm{~cm})$ compared to the DSS group $(P=0.0001$, Figure 1(b)). DSS induced colitis resulted in significant body mass loss compared to CTRL group, irrespective of $\mathrm{HBO}_{2}$ treatment $(11.89 \pm 0.03 \%$ and $8.24 \pm 0.01 \%$ in the DSS and DSS $+\mathrm{HBO}_{2}$ group, resp.; $\left.P<0.001\right)$. Mice undergoing $\mathrm{HBO}_{2}$ presented with reduced body mass loss. CTRL and $\mathrm{CTRL}+\mathrm{HBO}_{2}$ gained body mass during the experiment, $8.25 \pm 0.2 \%$ and $0.33 \pm 0.01 \%$, respectively.

Histological assessment of the colon revealed severe inflammation and ulceration extending into the deep portions of the mucosa with loss of crypts and with increased number of lamina propria leukocytes in DSS group of mice. We also found structural changes of mucosa in the colonic tissue of DSS $+\mathrm{HBO}_{2}$ mice but with reduced infiltration of inflammatory cells and decreased crypt distortion. When compared to the DSS $+\mathrm{HBO}_{2}$ group, the DSS group had significantly higher total histological score as well as individual scores (see modified Geboes score in Section 2.3, Figure 1(d), $P<0.001$ ), except for the intraepithelial neutrophil infiltration score $(P=0.104)$.

Distribution of inflammatory cells among the peripheral lymphoid organs, including $\mathrm{Gr}-1^{+}$leukocytes (monocytes and neutrophils), F4/80 ${ }^{+}$leukocytes (monocytes), $\mathrm{CD}^{+}{ }^{+} \mathrm{T}$ lymphocytes, and $\mathrm{B} 220^{+}$B lymphocytes (Figure 2), was assessed at the end of the experiment. In the MLN, frequencies of Gr$1^{+}$cells did not differ among the experimental groups, while DSS induced a significant increase in $\mathrm{F} 4 / 80^{+}$and decrease in $\mathrm{CD}^{+}$cell frequencies $(P<0.05$ and $P=0.032$, resp.; Figure 2(b)). These findings in the DSS group were accompanied by a B-cell increase which was not statistically significant. $\mathrm{HBO}_{2}$ alone had no effect on the cell frequencies in MLN of control mice, whereas it substantially ameliorated these changes in mice with DSS-induced colitis (DSS + $\mathrm{HBO}_{2}$ group) but without reaching statistical significance.

In the spleen, $\mathrm{Gr}-1^{+}$cell frequencies were significantly decreased in the DSS group compared to CTRL $(P=0.006)$ and CTRL $+\mathrm{HBO}_{2}$ groups $(P<0.001$; Figure $2(\mathrm{a})) . \mathrm{HBO}_{2}$ treatment reversed $\mathrm{Gr}-\mathrm{1}^{+}$cell frequencies to control values in the DSS $+\mathrm{HBO}_{2}$ group $(P=0.056$; Figure $2(\mathrm{a}))$. In addition, the DSS mice showed reduced frequencies of $\mathrm{B} 220^{+}$ lymphocytes compared to the CTRL group $(P=0.016)$, and $\mathrm{HBO}_{2}$ treatment abolished these effects in the DSS + $\mathrm{HBO}_{2}$ group $(P=0.034$; Figure $2(\mathrm{c}))$. In addition, our study revealed that DSS-induced immune responses in the MLN and the spleen were significantly dampened by $\mathrm{HBO}_{2}$ treatment.

Frequency of $\mathrm{CD} 4^{+}$cells among the colon lamina propria lymphocytes of DSS and DSS $+\mathrm{HBO}_{2}$ groups was significantly increased compared to the CTRL group $(P=0.015$ and $P=0.047$, resp.), while the frequency of $\mathrm{CD}^{+}$cells was significantly increased only in the DSS group when compared to the CTRL group $(P=0.011$; Figure 3$)$.

3.2. Inflammation of Colonic Mucosa and $\mathrm{HBO}_{2}$ Treatment Induce Changes in Antioxidative Enzymes Gene Expression and HIF-1 $\alpha$ Gene Regulation. Inflammatory conditions have been known to include the enhanced production of ROS and other oxidative mediators that may affect transcriptional regulation via $H I F-1 \alpha$. To investigate the role of $H I F-$ $1 \alpha$ in the regulation of the antioxidative response/capacity during DSS-induced colitis and $\mathrm{HBO}_{2}$ treatment, $H I F-1 \alpha$, CAT, GPX1, and SOD1 mRNA expressions were determined using quantitative PCR method. HIF- $1 \alpha$ mRNA expression was significantly changed by the $\mathrm{HBO}_{2}$ treatment and the inflammatory microenvironment in the gut mucosa. DSSinduced colitis resulted in significant upregulation of $H I F-1 \alpha$ gene in colonic mucosa $(P=0.008$ for DSS group compared to CTRL), and the $\mathrm{HBO}_{2}$ treatment further increased HIF$1 \alpha$ mRNA expression in the DSS $+\mathrm{HBO}_{2}$ group $(P=$ 0.028 compared to CTRL; Figure 3(a)). In addition, the activity of $H I F-1 \alpha$ protein was indirectly confirmed by measuring mRNA expression of well-established HIF-1 $\alpha$ target genes, VEGF and PGK1. Both genes showed strong positive correlation to the HIF- $1 \alpha$ mRNA (Supplementary Figure 1) (see Supplementary Material available online at http://dx.doi.org/10.1155/2016/7141430). There was also a tendency for upregulation of HIF-1 $\alpha$ gene in MLN and spleens of the DSS group and its downregulation via $\mathrm{HBO}_{2}$ in the DSS $+\mathrm{HBO}_{2}$ group (Figure 4(a)); however, these changes did not reach statistical significance.

Inflammation during DSS-induced colitis and the $\mathrm{HBO}_{2}$ treatment also induced significant changes in mRNA expression of target antioxidative genes. DSS-treated mice presented with significant downregulation of the CAT gene in the colon compared to the CTRL group $(P=0.031)$, while there was a significant upregulation of CAT gene in the spleen of 


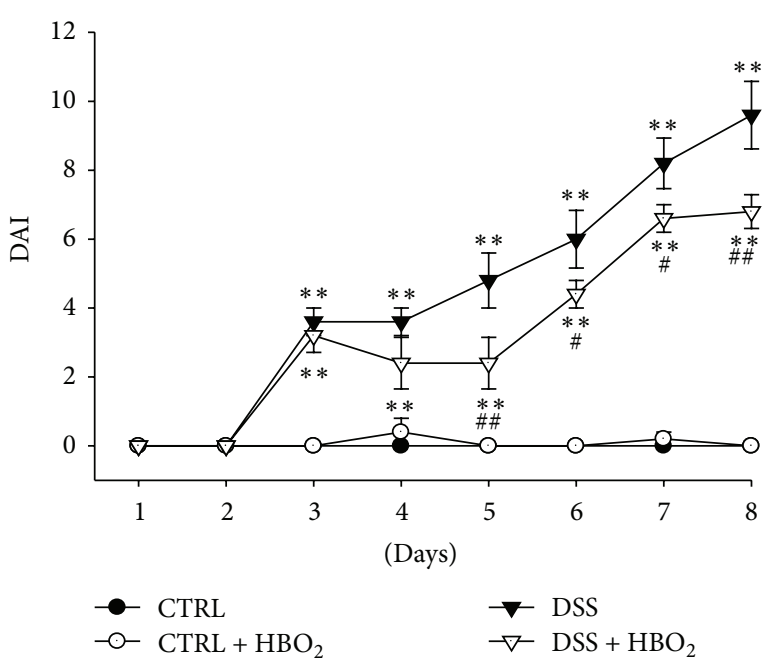

(a)

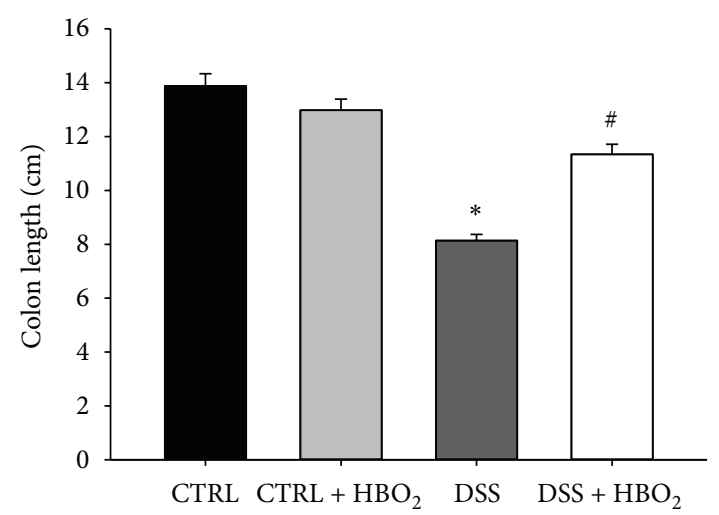

(c)
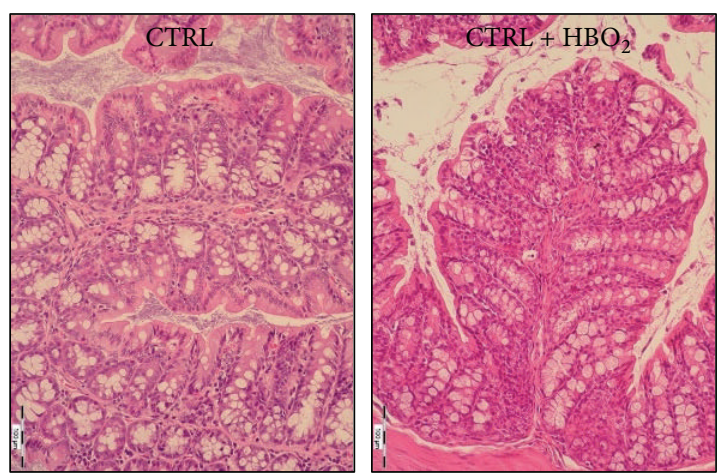

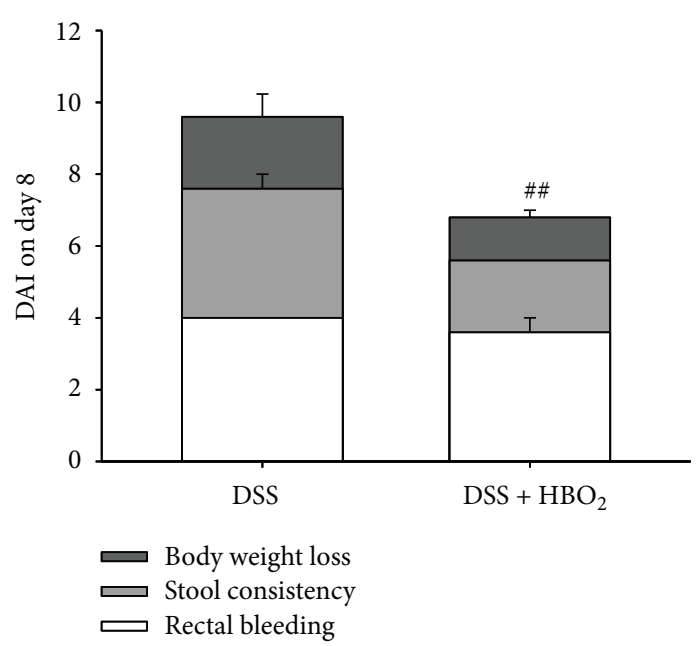

(b)

Colon

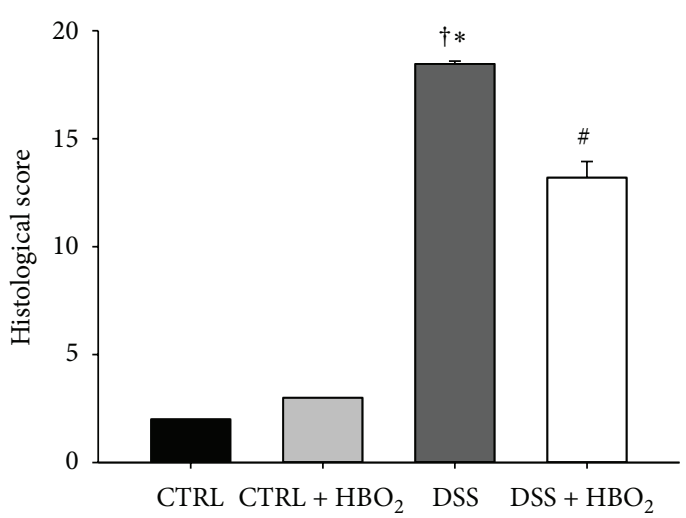

(d)
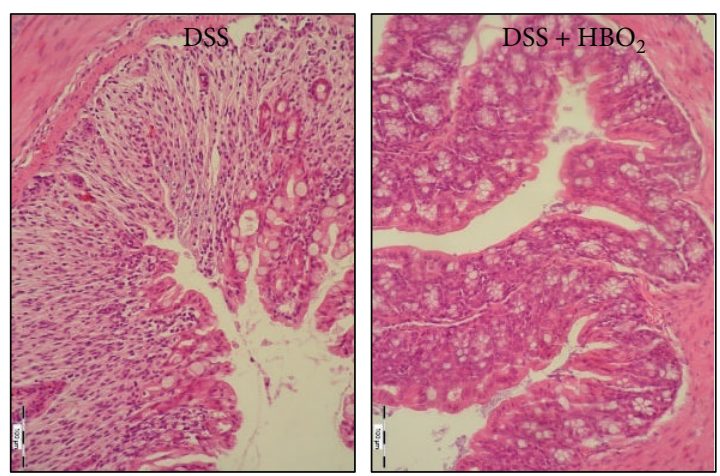

(e)

FIgURE 1: $\mathrm{HBO}_{2}$ ameliorates the course of DSS-induced colitis in BALB/c mice. Male BALB/c mice at the age of 10-12 weeks were randomly assigned into 4 groups $\left(n=5\right.$ mice/group/experiment): CTRL: control mice, CTRL $+\mathrm{HBO}_{2}$ : control mice undergoing $\mathrm{HBO}_{2}$ (60 min/2.4 ATM, 2x/day, days 1-8), DSS: mice receiving dextran sodium sulphate (5\% w/v, days 1-7), and $\mathrm{DSS}^{+} \mathrm{HBO}_{2}$ : DSS treated mice undergoing $\mathrm{HBO}_{2}$. (a) Disease activity index (DAI) assessed by daily scoring of the body weight change, stool consistency, and occult/gross rectal bleeding; (b) the stacked bars on the bar chart represent average score of each symptom in the total DAI score for particular experimental group, including weight changes, stool consistency, and rectal bleeding score; (c) colon length measured in cm; (d) histological samples of gut tissue were stained with haematoxylin and eosin and severity of colitis assessed using modified Geboes score; (e) representative histological samples of distal colon, CTRL and CTRL $+\mathrm{HBO}_{2}$ : normal intact colonic mucosa, DSS: the mucosa shows severe inflammation and ulceration extending into the deep portions of the mucosa with loss of crypts, and DSS $+\mathrm{HBO}_{2}$ : structural restoration with mild inflammatory infiltration and crypt distortion; magnification 200x. Presented data (mean \pm s.e.m.) are representative results from one experiment with $n=$ min. 5 mice/group. ${ }^{*}$ Statistically different from CTRL $P<0.05$ and ${ }^{* *} P<0.01$; ${ }^{\#}$ statistically different from DSS $P<0.05$ and ${ }^{\# \#} P<0.01$; ${ }^{\dagger}$ statistically different from CTRL $+\mathrm{HBO}_{2}$. 

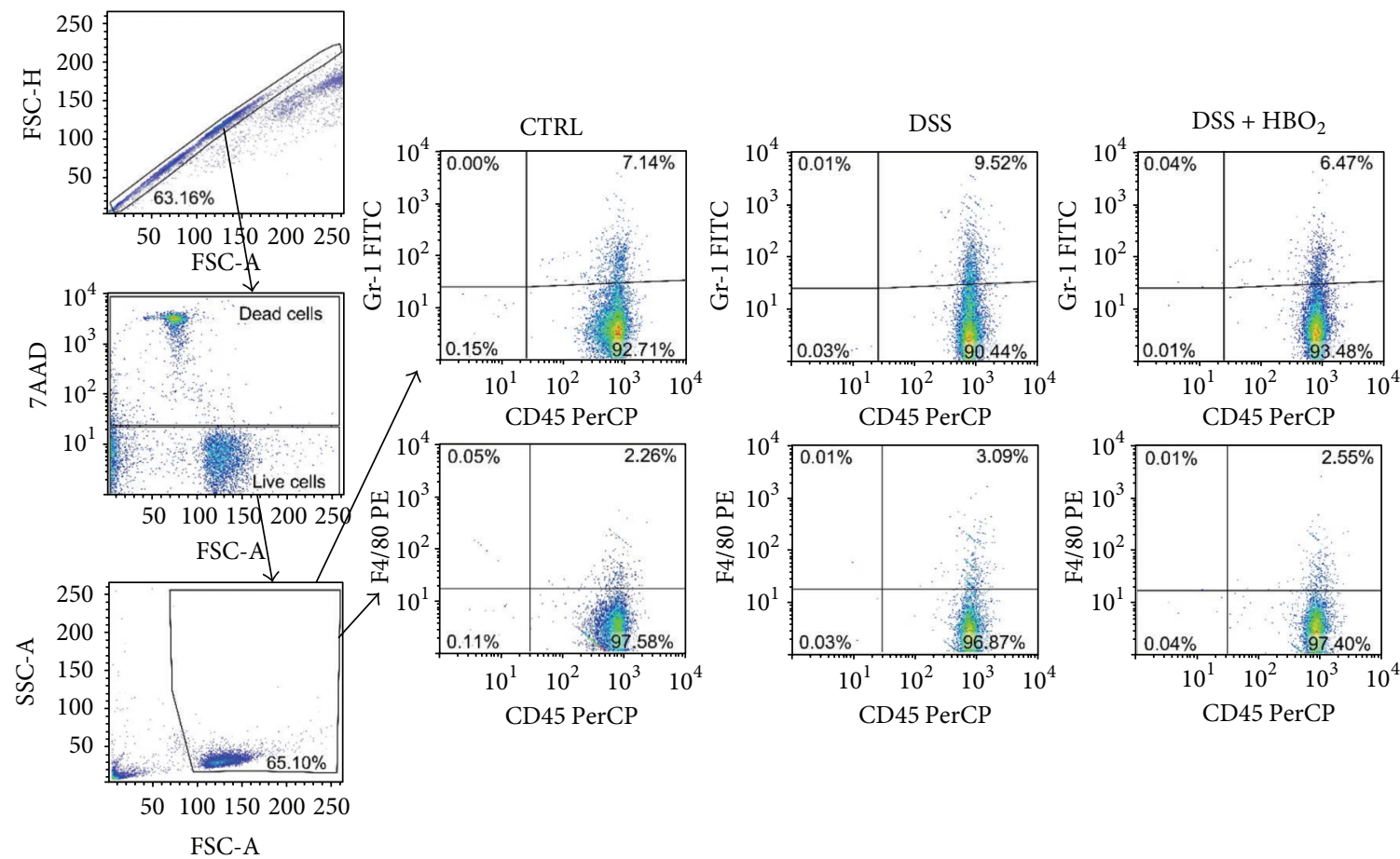

CD45 PerCP

CD45 PerCP

CD45 PerCP

MLN Gr- $1^{+}$

MLN F4/ $80^{+}$
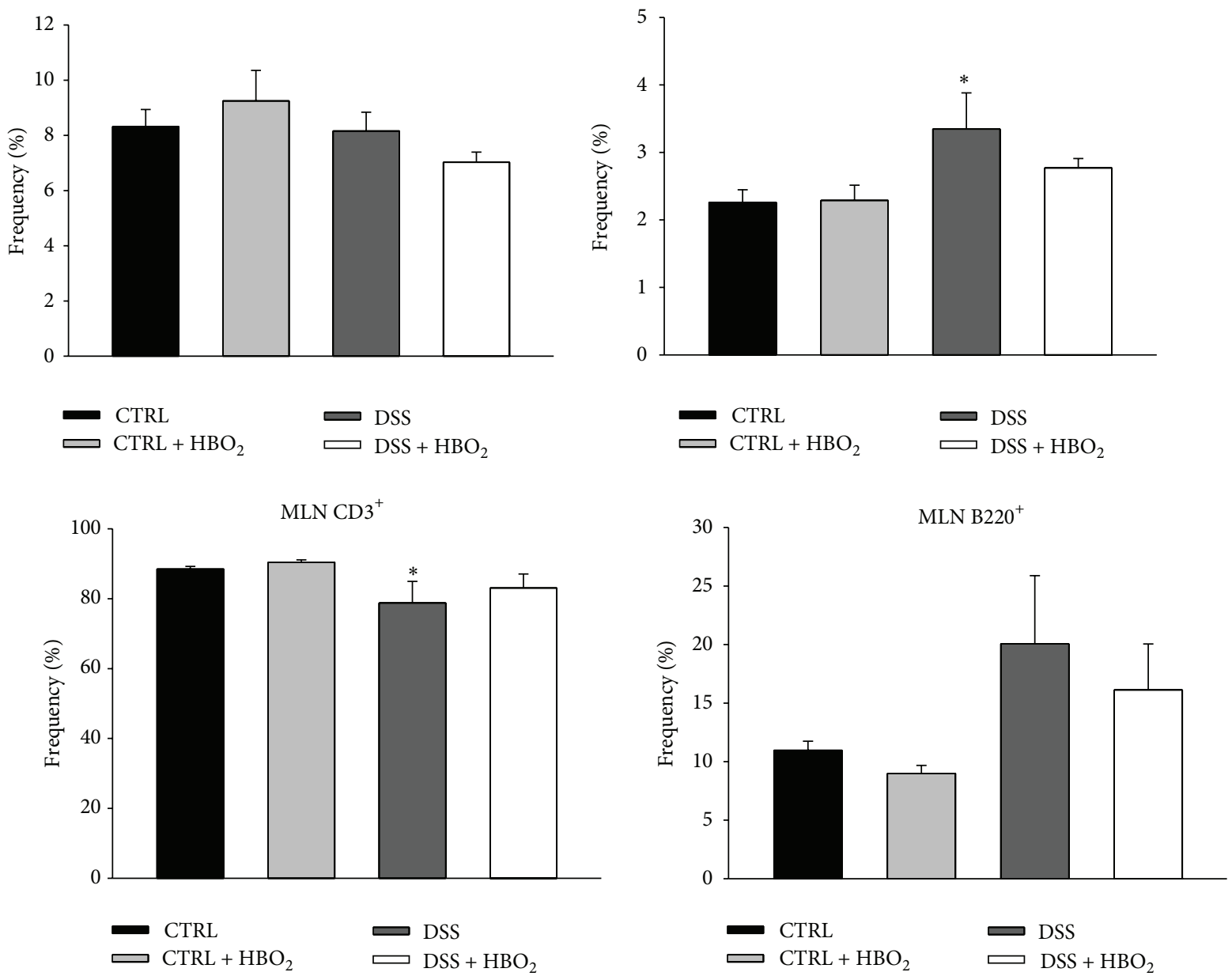

(b)

Figure 2: Continued. 

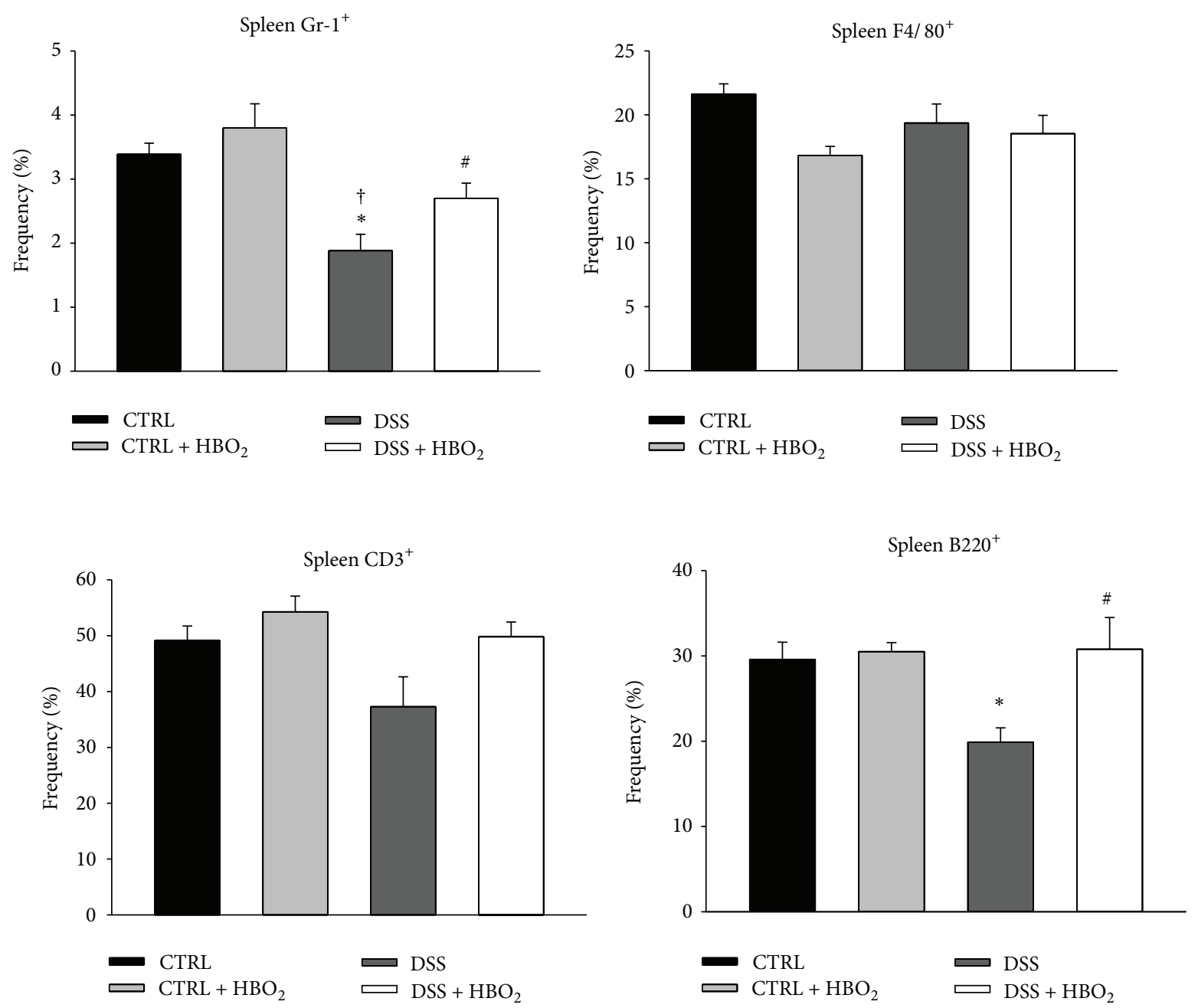

(c)

FIGURE 2: $\mathrm{HBO}_{2}$ changes immune cell frequencies in the mesenteric lymph nodes (MLN) and the spleen of BALB/c mice with DSS induced colitis. BALB/c mice at the age of $10-12$ weeks were randomly assigned into 4 groups $(n=\mathrm{min} .5 \mathrm{mice} /$ group/experiment): CTRL: control mice, CTRL $+\mathrm{HBO}_{2}$ : control mice undergoing $\mathrm{HBO}_{2}(60 \mathrm{~min} / 2.4 \mathrm{ATM}, 2 \mathrm{x} /$ day, days 1-8), DSS: mice receiving dextran sodium sulphate (DSS, $5 \% \mathrm{w} / \mathrm{v}$, days 1-7), and DSS $+\mathrm{HBO}_{2}$ : DSS treated mice undergoing $\mathrm{HBO}_{2}$. Representative dot plots of MLN obtained by flow cytometry, illustrating the gating strategy for $\mathrm{CD}_{4} 5^{+} \mathrm{Gr}-1^{+}$and $\mathrm{CD} 45^{+} \mathrm{F} 4 / 80^{+}$cells in MLN of CTRL, DSS, and DSS + $\mathrm{HBO}_{2}$ groups. Doublets were excluded by forward scatter area (FSC-A) versus forward scatter height (FSC-H) and the dead cells using 7-AAD. (a) Frequency of CD45 ${ }^{+}$ Gr $-1^{+}$cells, $\mathrm{CD} 45^{+} \mathrm{F} 4 / 80^{+}$cells, $\mathrm{CD}^{+} \mathrm{T}$ cells, and B $220^{+} \mathrm{B}$ cells in MLN (b) and spleen (c). Data are presented as mean \pm s.e.m. $\%$ of single, live leukocytes (for $\mathrm{Gr}-1^{+}$and $\mathrm{F} 4 / 80^{+}$cells) or single, live lymphocytes (for $\mathrm{CD} 3^{+}$and $\mathrm{B} 220^{+}$cells). ${ }^{*}$ Statistically different from $\mathrm{CTRL}, P<0.05$; ${ }^{\dagger}$ statistically different from CTRL $+\mathrm{HBO}_{2}, P<0.05$; ${ }^{*}$ statistically different from DSS, $P<0.05 .7$-AAD, 7-aminoactinomycin D.

the DSS $+\mathrm{HBO}_{2}$ mice compared to the CTRL group $(P=$ 0.026 ; Figure $4(\mathrm{~b}))$. In the colon, GPx1 mRNA expression was increased in the DSS $(P=0.034)$ and the DSS $+\mathrm{HBO}_{2}(P=$ 0.003 ) group compared to CTRL group. The upregulation was even greater in mice with DSS-induced colitis that underwent the $\mathrm{HBO}_{2}$ treatment (DSS $+\mathrm{HBO}_{2}$ group; Figure 4(b)). SOD1 mRNA expression was significantly reduced in the colon of the DSS $+\mathrm{HBO}_{2}$ group compared to CTRL $(P=0.008)$ and $\mathrm{CTRL}+\mathrm{HBO}_{2}(P=0.007)$ groups. Similar changes in SOD1 gene expression were also found in the MLN of the DSS + $\mathrm{HBO}_{2}$ group $(P=0.025$ compared to CTRL; Figure 4(b)). To summarize, colitis resulted in GPx1 gene upregulation and $C A T$ gene downregulation, while $\mathrm{HBO}_{2}$ downregulated
SOD1 and further upregulated GPX1 in a tissue-specific manner.

To examine the possible role of HIF-1 $\alpha$ in transcriptional control of antioxidative genes in the colon, Spearman correlations were calculated. The results revealed a strong negative correlation between HIF-1 $\alpha$ and SOD1 $(r=-0.651$, $P=0.001)$ and a positive correlation of HIF-1 $\alpha$ to the GPX1 gene $(r=0.750, P<0.001)$, while there was no significant correlation between the HIF-1 $\alpha$ and the CAT gene in the colonic tissue (Figure 4(c)).

3.3. $\mathrm{HBO}_{2}$ Treatment Reduces Expression of Proinflammatory Genes Upregulated during DSS-Induced Colitis. The early 

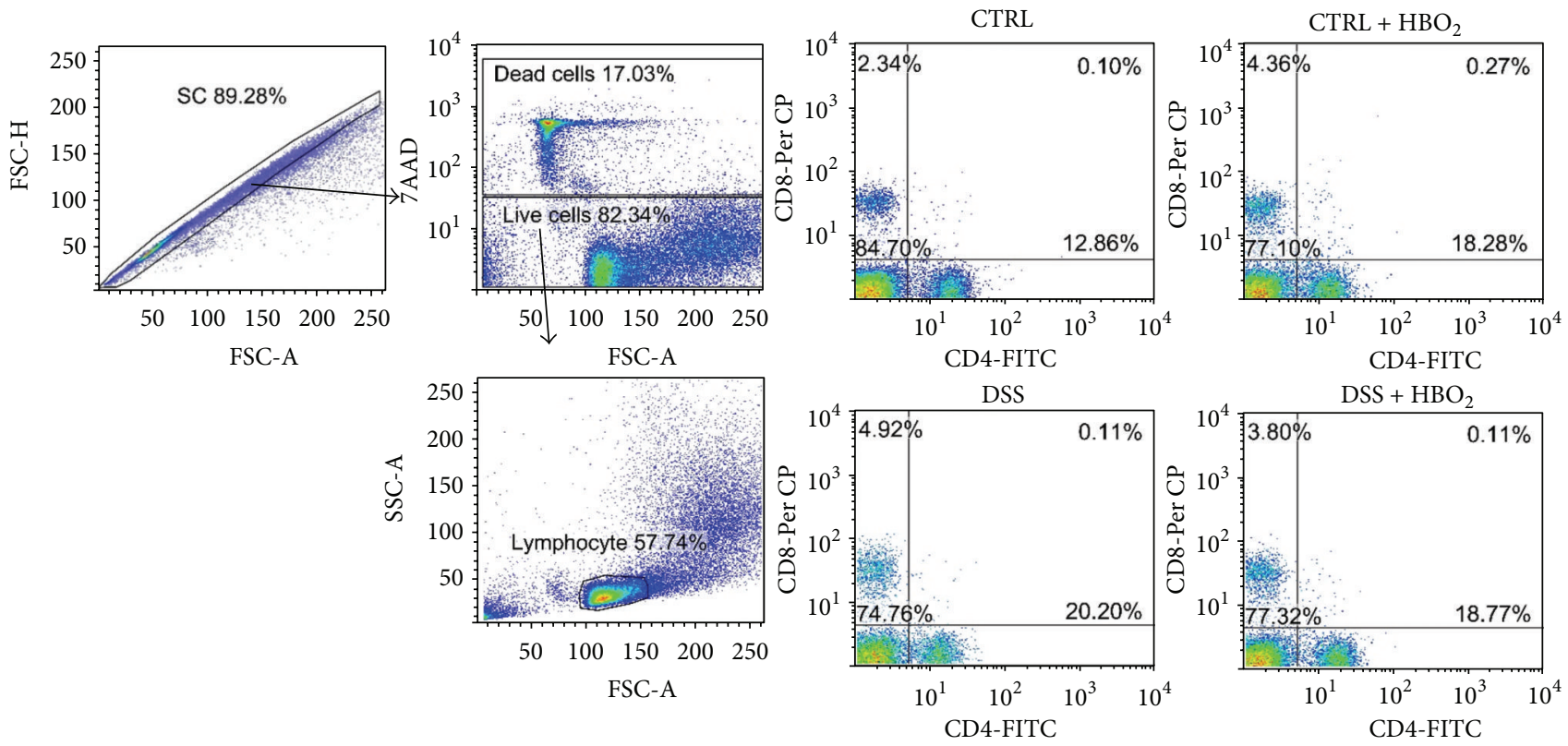

(a)
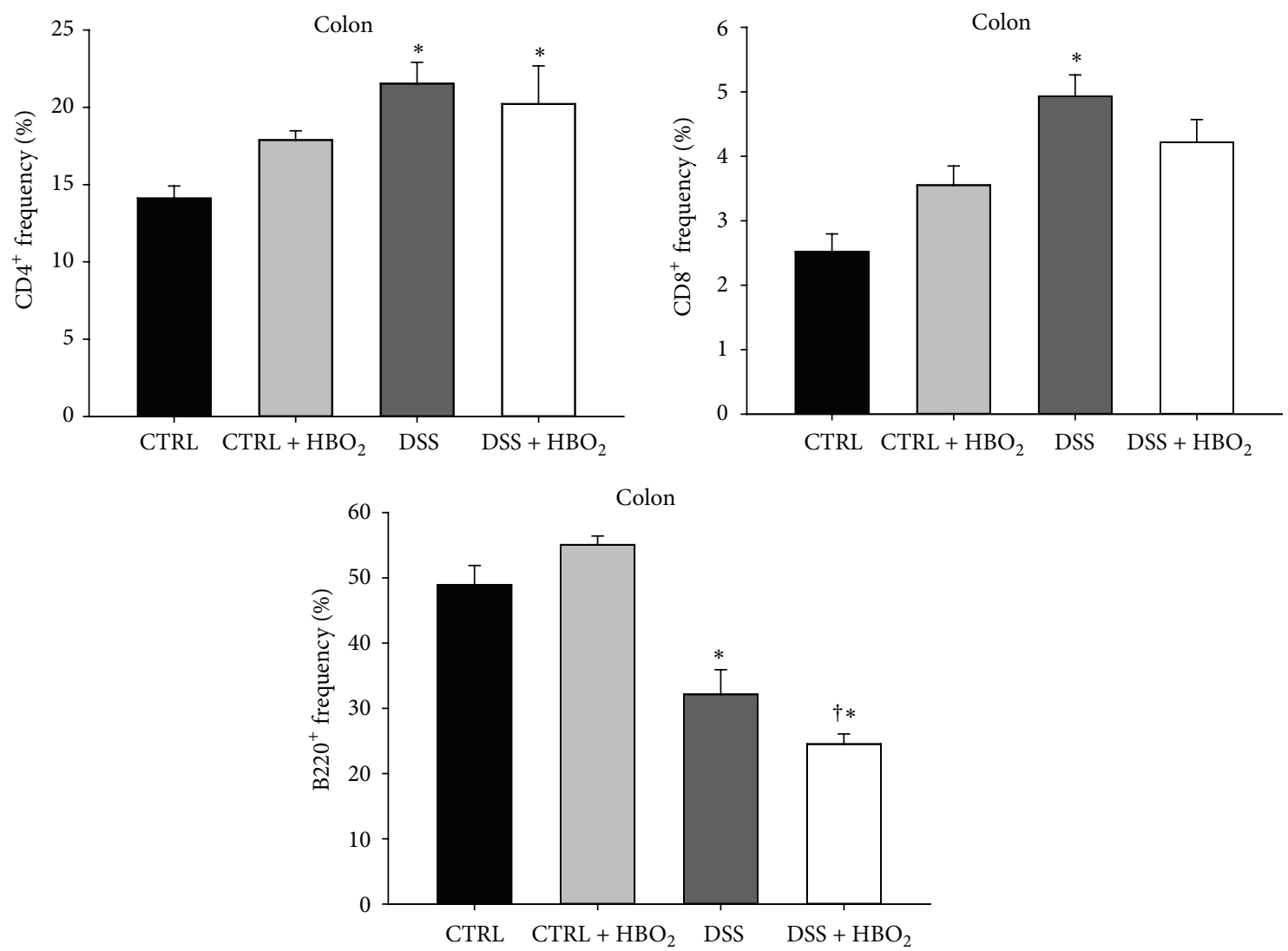

(b)

FIGURE 3: $\mathrm{HBO}_{2}$ induced changes in $\mathrm{CD} 4^{+}$and $\mathrm{CD}^{+} \mathrm{T}$ cell frequencies in the colon of BALB/c mice with DSS induced colitis. BALB/c mice at the age of 10-12 weeks were randomly assigned into 4 groups $(n=\mathrm{min} .4$ mice/group/experiment): CTRL: control mice, CTRL + $\mathrm{HBO}_{2}$ : control mice undergoing $\mathrm{HBO}_{2}(60 \mathrm{~min} / 2.4 \mathrm{ATM}, 2 \mathrm{x} /$ day, days 1-8), DSS: mice receiving dextran sodium sulphate (DSS, $5 \% \mathrm{w} / \mathrm{v}$, days 1-7), and DSS $+\mathrm{HBO}_{2}$ : DSS treated mice undergoing $\mathrm{HBO}_{2}$. (a) Representative dot plots of colon lamina propria lymphocyte obtained by flow cytometry, illustrating the gating strategy for $\mathrm{CD}^{+}$and $\mathrm{CD} 8^{+}$lymphocytes, and (b) measured frequencies of colon $\mathrm{CD} 4^{+}$and $\mathrm{CD} 8^{+}$ lymphocytes. Doublets were excluded by forward scatter area (FSC-A) versus forward scatter height (FSC-H) and the dead cells using 7-AAD. Data are presented as mean \pm s.e.m. $\%$ of single, live lymphocytes. ${ }^{*}$ Statistically different from CTRL, $P<0.05$; ${ }^{\dagger}$ statistically different from $\mathrm{CTRL}+\mathrm{HBO}_{2}$. 


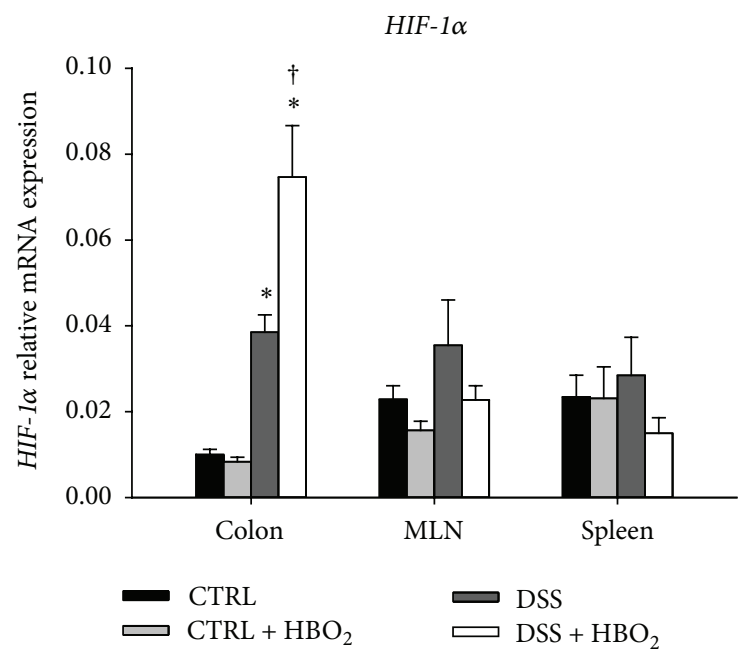

(a)
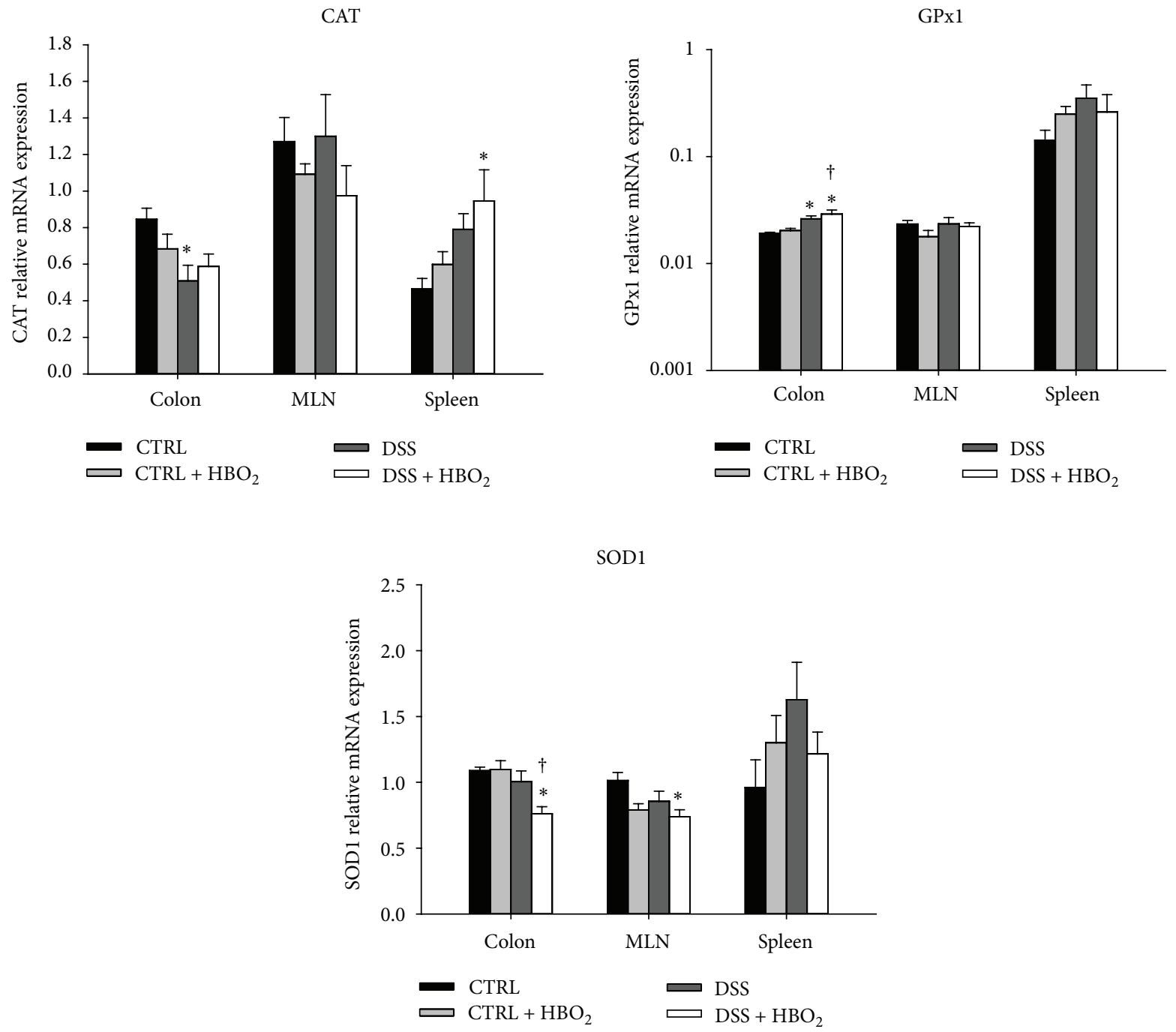

(b)

Figure 4: Continued. 

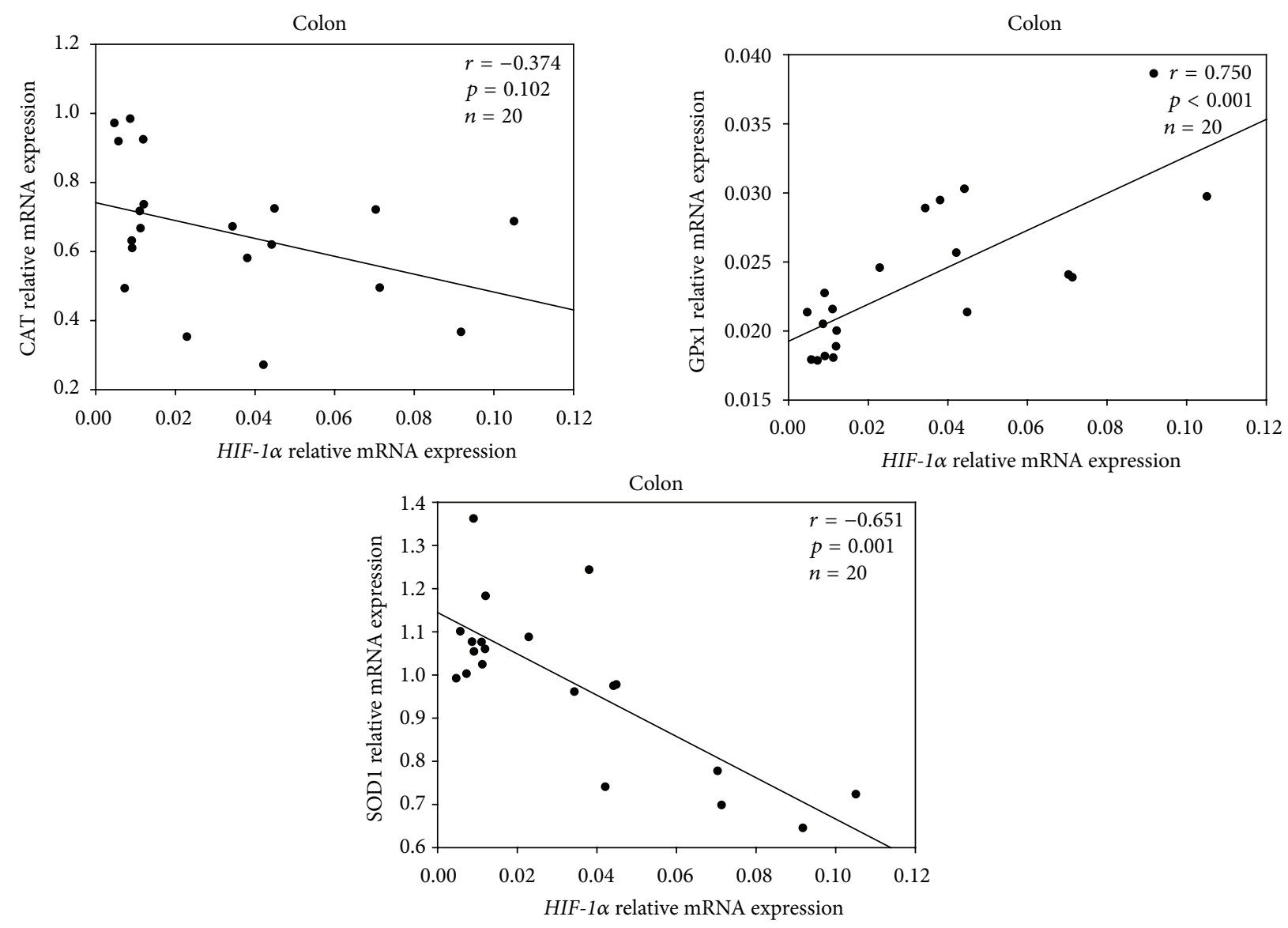

(c)

Figure 4: Relative mRNA expression of HIF-1 $\alpha$, CAT, GPxl, and SOD1 in colon, MLN, and spleen (a, b) and their correlation to the HIF-1 $\alpha$ gene expression in colonic tissue (c). Relative mRNA expression was measured by real-time PCR; all measured genes were normalized to the HPRT1 gene expression. BALB/c mice at the age of 10-12 weeks were randomly assigned into 4 groups $(n=$ min. $5 /$ group/experiments): CTRL: control mice, CTRL $+\mathrm{HBO}_{2}$ : control mice undergoing $\mathrm{HBO}_{2}(60 \mathrm{~min} / 2.4 \mathrm{ATM}, 2 \mathrm{x} /$ day, days 1-8), DSS: mice receiving dextran sodium sulphate (DSS, $5 \% \mathrm{w} / \mathrm{v}$, days 1-7), and DSS $+\mathrm{HBO}_{2}$ : DSS treated mice undergoing $\mathrm{HBO}_{2}$. Data are presented as mean \pm s.e.m. of two independent experiments, each with min. 5 mice/group. ${ }^{*}$ Statistically different from CTRL, $P<0.05$; ${ }^{\dagger}$ statistically different from CTRL $+\mathrm{HBO}_{2}, P<0.05$.

phase of inflammation is mediated by several proinflammatory mediators, which prompted us to assess how $\mathrm{HBO}_{2}$ treatment affects their production. We found that gut mucosa inflammation was accompanied with a significant increase in $I L-1 \beta$ and $I L-6$ gene expression. In the case of $I L-6$ gene, this was significant for DSS and DSS $+\mathrm{HBO}_{2}$ groups compared to the CTRL $+\mathrm{HBO}_{2}$ group $(P=0.024$ and $P=0.021$, resp.; Figure 5(a)) in the colon. Furthermore, $I L-6$ gene was significantly upregulated in the MLN of the DSS group $(P=$ 0.001 compared to CTRL), and $\mathrm{HBO}_{2}$ reduced its expression almost to control values in the $\mathrm{DSS}+\mathrm{HBO}_{2}$ group $(P=0.016$ compared to DSS; Figure 5(a)). IL-1 $\beta$ mRNA expression in the colonic mucosa was significantly increased during inflammation in DSS group compared to CTRL $(P=0.014)$ and CTRL $+\mathrm{HBO}_{2}$ groups $(P=0.041) . I L-1 \beta$ mRNA levels in the colon of the DSS $+\mathrm{HBO}_{2}$ group did not significantly differ from the control groups, suggesting that $\mathrm{HBO}_{2}$ treatment blocked the increase of $I L-1 \beta$ gene expression in the inflamed mucosa.

IL-2 gene was significantly upregulated in the MLN of the DSS group compared to the CTRL group $(P=0.003)$, and
$\mathrm{HBO}_{2}$ treatment resulted in its significant downregulation in the DSS $+\mathrm{HBO}_{2}$ group $(P=0.032)$. Similarly, $I L-2$ gene was significantly downregulated in the spleen of mice from the DSS $+\mathrm{HBO}_{2}$ group compared to the CTRL group $(P=$ $0.025)$. In addition, there was a strong positive correlation between HIF- $1 \alpha$ and $I L-6$ gene $(r=0.749, P<0.001$; Figure 5(b)), while there was no correlation between $H I F-1 \alpha$ and $I L-1 \beta$ or $I L-2$ genes in the colonic tissue (Figure 5(b)).

3.4. Colonic Inflammation and $\mathrm{HBO}_{2}$ Treatment Induce Changes in the Activity of Antioxidative Enzymes. In addition to their mRNA expression, we also tested the enzymatic activity of antioxidative enzymes. We found that both the inflammation and the $\mathrm{HBO}_{2}$ treatment per se were able to change the activity of antioxidative enzymes in the colonic mucosa and the peripheral lymphoid organs (MLN and spleen). In spleen $\mathrm{HBO}_{2}$ treatment per se induced significant increase of SOD activity $(P=0.040$ compared to CTRL). Mice with DSSinduced colitis presented with significantly increased activity of SOD ( $P=0.012$ compared to CTRL) in the colon and reduced CAT activity in MLN and spleen $(P=0.023$ and 

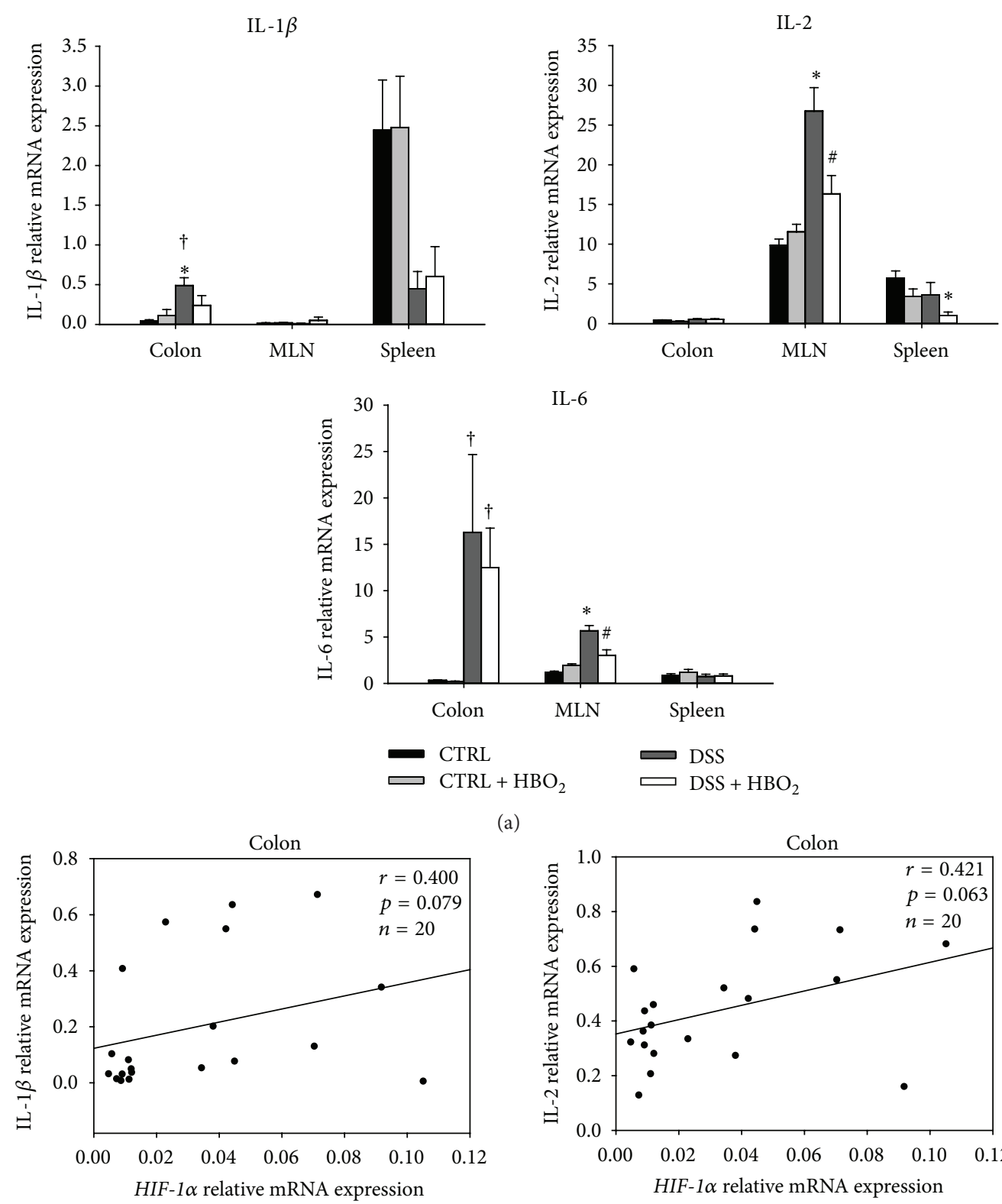

(a)
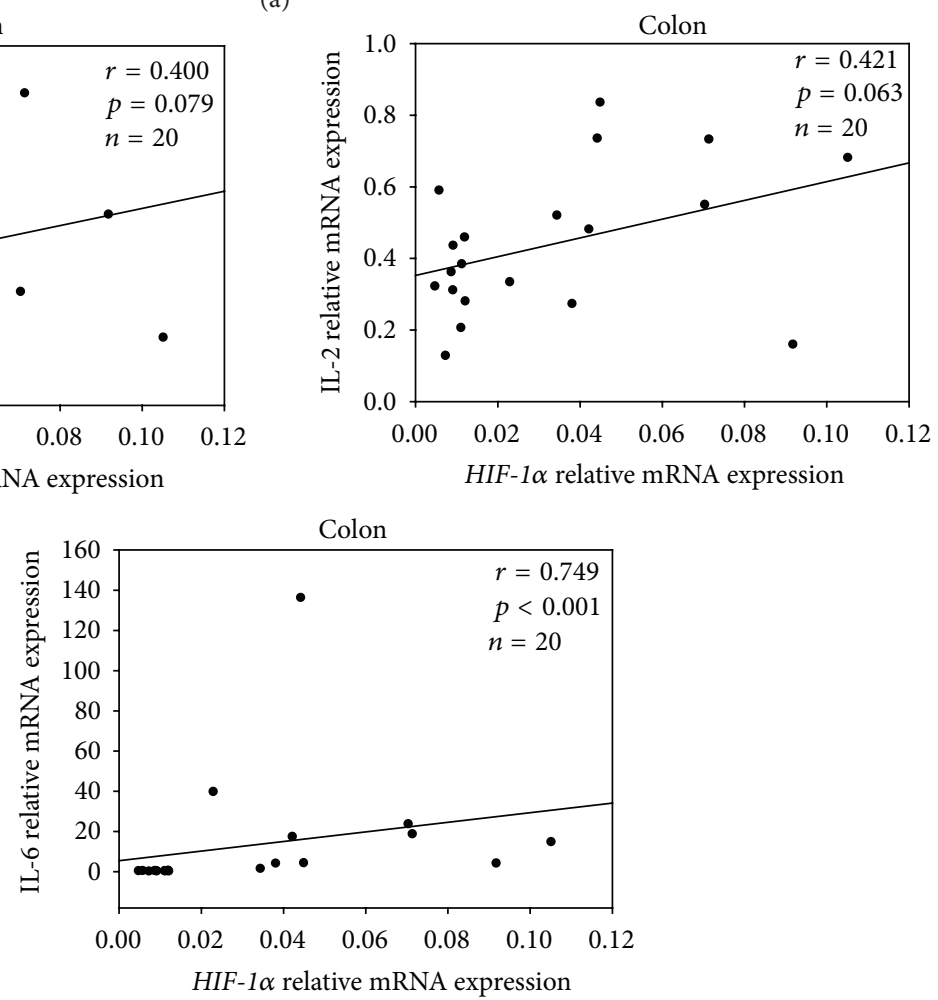

(b)

FIGURE 5: Relative mRNA expression of $I L-1 \beta, I L-2$, and $I L-6$ in the colon, MLN, and spleen (a) and their correlation to HIF-1 $\alpha$ gene expression in colonic tissue (b). Relative mRNA expression was measured by real-time PCR; all measured genes were normalized to expression of HPRT1 gene. $\mathrm{BALB} / \mathrm{c}$ mice at the age of $10-12$ weeks were randomly assigned into 4 groups $(n=\mathrm{min}$. 5/group/experiment): CTRL: control mice, CTRL $+\mathrm{HBO}_{2}$ : control mice undergoing $\mathrm{HBO}_{2}(60 \mathrm{~min} / 2.4 \mathrm{ATM}, 2 \mathrm{x} /$ day, days 1-8), DSS: mice receiving dextran sodium sulphate (DSS, $5 \%$ w/v, days 1-7), and DSS $+\mathrm{HBO}_{2}$ : DSS treated mice undergoing $\mathrm{HBO}_{2}$. Data are presented as mean \pm s.e.m.; ${ }^{*}$ statistically different from CTRL, $P<0.05$; $^{*}$ statistically different from DSS, $P<0.05$; $^{\dagger}$ statistically different from CTRL $+\mathrm{HBO}_{2}, P<0.05$. 
$P=0.032$, resp.) compared to CTRL group. $\mathrm{HBO}_{2}$ treatment did not change SOD activity in the inflamed colonic mucosa, which was comparable to the levels found in DSS and CTRL $+\mathrm{HBO}_{2}$ groups (significantly increased compared to CTRL, $P=0.010)$. On the other hand, $\mathrm{HBO}_{2}$ treatment significantly increased CAT $(P=0.020)$ and $\operatorname{GPx}(P=0.001)$ activities in the spleens of the DSS $+\mathrm{HBO}_{2}$.

3.5. Lymphocyte $\mathrm{H}_{2} \mathrm{O}_{2}$ and $\mathrm{ONOO}^{-}$Production Remains Unchanged during DSS-Induced Colitis and $\mathrm{HBO}_{2}$ Treatment. Immune cells at the site of inflammation and in the peripheral lymphoid organs are an important source of ROS [3]. Therefore we assessed the basal levels of intracellular $\mathrm{H}_{2} \mathrm{O}_{2}$ and $\mathrm{ONOO}^{-}$and their production upon PMA-induced activation in the lymphocytes isolated from MLN and spleens of the mice from all experimental groups (Figure 6). Basal $\mathrm{H}_{2} \mathrm{O}_{2}$ and $\mathrm{ONOO}^{-}$production in the MLN was not significantly different among the groups, except for the lymphocytes from the DSS $+\mathrm{HBO}_{2}$ group which presented with a significant increase of $\mathrm{H}_{2} \mathrm{O}_{2}$ and $\mathrm{ONOO}^{-}$levels compared to the CTRL group $(P=0.033)$. PMA stimulation resulted in increased intracellular $\mathrm{H}_{2} \mathrm{O}_{2}$ and $\mathrm{ONOO}^{-}$production, although statistically significant only for CTRL $(P=0.031)$ and DSS + $\mathrm{HBO}_{2}(P=0.012)$ groups.

In the spleen, $\mathrm{HBO}_{2}$ increased lymphocyte $\mathrm{H}_{2} \mathrm{O}_{2}$ and $\mathrm{ONOO}^{-}$production in CTRL $+\mathrm{HBO}_{2}$ and $\mathrm{DSS}+\mathrm{HBO}_{2}$ groups ( $P=0.004$ and $P=0.007$ compared to the CTRL; and $P=0.005$ and $P=0.009$ compared to the DSS group). Their production after PMA-induced activation was decreased in all experimental groups except the CTRL group; however, this effect reached statistical significance only in the $\mathrm{CTRL}+\mathrm{HBO}_{2}$ group $(P=0.018$ compared to unstimulated lymphocytes).

\section{Discussion}

In the present study, the experimental model of DSS-induced colitis in $\mathrm{BALB} / \mathrm{c}$ mice was employed to explore the effects of $\mathrm{HBO}_{2}$ on the antioxidative enzymes, transcription factor $H I F-1 \alpha$, and proinflammatory cytokine genes during colonic inflammation and their role in modulating the course of the disease via $\mathrm{HBO}_{2}$ treatment. The most important findings are that (a) $\mathrm{HBO}_{2}$ significantly reduces symptoms and severity of DSS-induced colitis, as evidenced by clinical appearance, contraction of the immune cell expansion and mobilization, and reversal of $I L-1 \beta, I L-2$, and $I L-6$ gene expression; (b) $\mathrm{HBO}_{2}$ modulates the expression of antioxidative enzyme genes and enzyme activities during colitis; and (c) $\mathrm{HBO}_{2}$ enhances HIF-1 $\alpha$ mRNA expression in the inflamed colonic tissue which is in a strong correlation with GPx1, SOD1, and IL-6 mRNA expression.

Several previous studies in animals and humans demonstrated the positive effects of $\mathrm{HBO}_{2}$ treatment in influencing the severity of colitis and reducing gut mucosa inflammation $[27,34]$; however, data on the precise underlying mechanisms are scarce. Considerably more data on the beneficial antiinflammatory effects of $\mathrm{HBO}_{2}$ are available for other conditions such as septic shock, ischemia/reperfusion injuries, and atherogenesis, where the previous studies reported reduced proinflammatory cytokine expression, suppressed development of Th cells, shrinking of spleen and lymph nodes, decreased responses to antigens, and reduced frequencies of circulating leukocytes [35-42]. Although this is the first animal study investigating the effects of $\mathrm{HBO}_{2}$ performed on DSS-induced colitis in $\mathrm{BALB} / \mathrm{c}$ mice and correlating it with the immune cell frequencies, our results are in line with previous findings on the changes associated with DSSinduced acute immune response, as well as on the effects of $\mathrm{HBO}_{2}$ on the antioxidative enzyme activities determined in other animal models, such as TNBS and acetic acid induced colitis in rats [27, 43,44]. During colitis mice presented with decreased $\mathrm{T}$ and $\mathrm{B}$ cell frequencies in the spleen and reduced $\mathrm{T}$ cell frequencies in the MLN, suggesting that lymphocytes are recruited from the peripheral lymphoid organs and probably migrate to the inflamed colonic mucosa. One element of the beneficial effect of $\mathrm{HBO}_{2}$ may be linked to normalized T and B cells frequency in the MLN and spleen of mice with DSS-induced colitis after hyperbaric treatment (Figures 1 and 2). By measuring CD4 and CD8 lymphocyte in colon we confirm our hypothesis of T-cell recruitment from the peripheral lymphoid organs and their migration to the inflamed colonic mucosa, as well as immunomodulatory effect of $\mathrm{HBO}_{2}$. In our model $\mathrm{HBO}_{2}$ did not affect cell frequencies in the peripheral lymphoid organs of control mice, in contrast to previous findings where $\mathrm{HBO}_{2}$ treatment per se was able to change lymphocyte subset populations in the spleen [45]. The observed differences may be due to different oxygen tension applied in our study.

For a long time macrophages and neutrophils have been considered as immune cells exclusively producing proinflammatory cytokines, chemokines, and large amounts of ROS/RNS contributing to aggravated inflammation. We have found decreased spleen Gr-1 $1^{+}$cell frequencies during colitis and their normalization upon $\mathrm{HBO}_{2}$ treatment (Figure 2). In addition, we showed increased MLN frequencies of $\mathrm{F} 4 / 80^{+}$cells in DSS group, while $\mathrm{HBO}_{2}$ treatment reversed their frequencies almost to control values. These findings indicate that $\mathrm{HBO}_{2}$ can modulate distribution of phagocytes by retaining neutrophils in the spleen and instigating macrophage migration towards the site of inflammation, in agreement with previous findings describing inhibited neutrophil infiltration into the gut of mice with DSS-induced colitis [46]. Furthermore, $\mathrm{HBO}_{2}$ treatment alone did not change the expression of proinflammatory cytokines in the colon, MLN, or spleen of the control mice; however, DSSinduced colitis resulted in a significant $I L-1 \beta$ and $I L-6$ gene upregulation in the colonic tissue and $I L-2$ gene upregulation in the MLN (Figure 5). Consistent with previous studies, $\mathrm{HBO}_{2}$ treatment abolished these effects, further confirming its anti-inflammatory potential [47-49].

Several animal studies on the effects of $\mathrm{HBO}_{2}$ on the experimental colitis reported an increased antioxidative capacity and changes in antioxidative enzyme activity [24, 25]. It has been proposed that an optimal $\mathrm{HBO}_{2}$ treatment could generate ROS which would function primarily as intermediates in the antioxidative signalling pathways leading to increased expression of antioxidative enzymes, reduced inflammation, and ameliorated colitis symptoms but would 

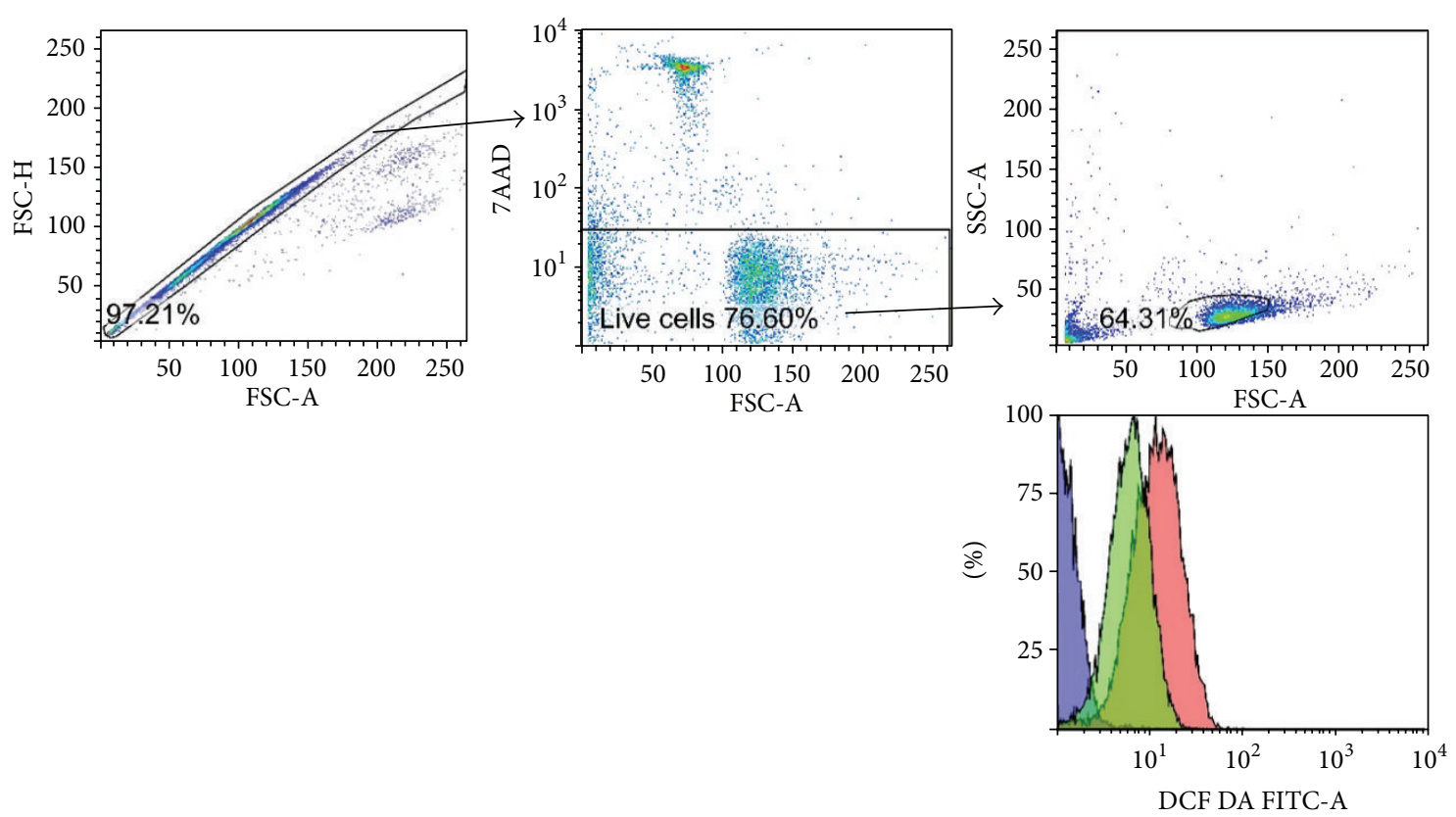

(a)
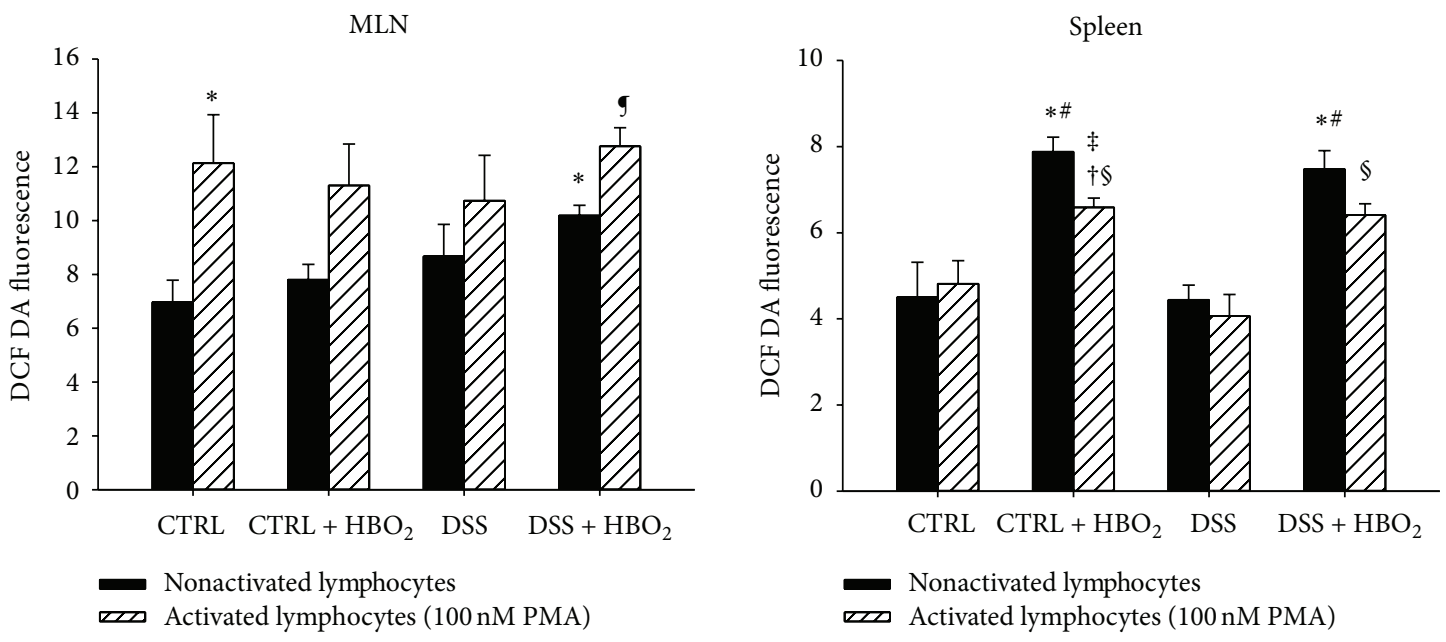

(b)

Figure 6: Lymphocyte $\mathrm{H}_{2} \mathrm{O}_{2}$ and $\mathrm{ONOO}^{-}$production during colitis and $\mathrm{HBO}_{2}$ treatment. $\mathrm{BALB} / \mathrm{c}$ mice at the age of 10-12 weeks were randomly assigned into 4 groups $\left(n=\mathrm{min} .4\right.$ mice/group/experiment): CTRL: control mice, $\mathrm{CTRL}+\mathrm{HBO}_{2}$ : control mice undergoing $\mathrm{HBO}_{2}$ (60 min/2.4 ATM, 2x/day, days 1-8), DSS: mice receiving dextran sodium sulphate (DSS, 5\% w/v, days 1-7), and DSS $+\mathrm{HBO}_{2}$ : DSS treated mice undergoing $\mathrm{HBO}_{2}$. To assess the basal intracellular $\mathrm{H}_{2} \mathrm{O}_{2}$ and $\mathrm{ONOO}^{-}$levels, lymphocytes isolated from MLN and spleens were stained with $10 \mu \mathrm{M}$ DCF DA and analysed by flow cytometry (black bars, (b)). Next, lymphocytes were activated with $100 \mathrm{nM}$ PMA for 30 min and the ROS production measurement repeated (lined white bars, (b)). (a) shows a representative lymphocyte gating strategy panel and a histogram of DCF-DA signal from the negative control (blue), resting lymphocytes (green), and the PMA activated lymphocytes (red). Doublets were excluded by forward scatter area (FSC-A) versus forward scatter height (FSC-H) and the dead cells by 7-AAD staining. Data are presented as mean \pm s.e.m.; ${ }^{*}$ statistically different compared to CTRL, $P<0.05$; ${ }^{*}$ statistically different compared to DSS group, $P<0.05 ;{ }^{\dagger}$ statistically different from CTRL $+\mathrm{HBO}_{2}, P<0.05$; ${ }^{\ddagger}$ statistically different compared to activated lymphocytes of CTRL group, $P<0.05$; ${ }^{\S}$ statistically different from the activated lymphocytes of DSS group, $P<0.05$. DCF DA: dichlorofluorescein diacetate; PMA: phorbol myristate acetate; 7-AAD: 7-aminoactinomycin D; ' statistically different from nonactivated lymphocytes DSS $+\mathrm{HBO}_{2}$.

not further damage the colonic tissue [50,51]. Drenjancevic et al. showed that 24 hours after a two-hour $\mathrm{HBO}_{2}$ treatment at 2 bars in rats oxidative stress is not elevated, as evidenced by assessing ferric reducing antioxidant power ability of plasma (FRAP) and thiobarbituric acid reactive substances (TBARS) level [12]. In addition, a recent study also suggests that ROS produced by NADPH oxidase complex are important mediators inducing anti-inflammatory response in autoimmune diseases [52]. Data on the CAT mRNA level during DSSinduced colitis and upon $\mathrm{HBO}_{2}$ treatment were not available prior to this study. We found that CAT mRNA expression is tissue and treatment specific (Figure 4). Colitis resulted 
TABLE 2: Catalase (CAT), glutathione peroxidase (GPx), and superoxide dismutase (SOD) activity in the colon, MLN, and spleen during colitis and $\mathrm{HBO}_{2}$ treatment.

\begin{tabular}{|c|c|c|c|c|c|}
\hline Enzymatic activity $\left(\mathrm{U} \mathrm{mg}^{-1} \mathrm{P}\right)$ & Tissue & CTRL & $\mathrm{CTRL}+\mathrm{HBO}_{2}$ & DSS & $\mathrm{DSS}+\mathrm{HBO}_{2}$ \\
\hline \multirow{3}{*}{ CAT } & Colon & $6.77 \pm 3.04$ & $5.39 \pm 1.07$ & $4.11 \pm 0.33$ & $4.23 \pm 0.20$ \\
\hline & MLN & $13.90 \pm 0.39$ & $11.78 \pm 1.71$ & $9.06 \pm 0.22^{*}$ & $12.62 \pm 0.42$ \\
\hline & Spleen & $10.44 \pm 1.94$ & $14.00 \pm 0.97$ & $6.75 \pm 0.53^{*}$ & $14.28 \pm 1.11^{\#}$ \\
\hline \multirow{3}{*}{ GPx } & Colon & $0.084 \pm 0.028$ & $0.097 \pm 0.012$ & $0.080 \pm 0.008$ & $0.072 \pm 0.003$ \\
\hline & MLN & $0.164 \pm 0.006$ & $0.158 \pm 0.021$ & $0.175 \pm 0.004$ & $0.172 \pm 0.007$ \\
\hline & Spleen & $0.098 \pm 0.005$ & $0.109 \pm 0.003$ & $0.114 \pm 0.007$ & $0.134 \pm 0.004^{* \dagger}$ \\
\hline \multirow{3}{*}{ SOD } & Colon & $15.40 \pm 3.29$ & $27.86 \pm 3.55^{*}$ & $30.56 \pm 2.70^{*}$ & $30.97 \pm 1.58^{*}$ \\
\hline & MLN & $36.53 \pm 2.80$ & $33.96 \pm 3.33$ & $34.48 \pm 1.62$ & $35.30 \pm 1.75$ \\
\hline & Spleen & $19.87 \pm 1.15$ & $17.91 \pm 0.72$ & $20.93 \pm 1.03$ & $25.34 \pm 1.61^{* \dagger}$ \\
\hline
\end{tabular}

$\mathrm{BALB} / \mathrm{c}$ mice at the age of 10-12 weeks were randomly assigned into 4 groups $\left(n=5 /\right.$ group): CTRL: control mice, $\mathrm{CTRL}+\mathrm{HBO}_{2}$ : control mice undergoing $\mathrm{HBO}_{2}\left(60 \mathrm{~min} / 2.4\right.$ ATM, 2x/day, days 1-8), DSS: mice receiving DSS (5\% w/v, days 1-7), and DSS $+\mathrm{HBO}_{2}$ : DSS treated mice undergoing $\mathrm{HBO}_{2}$. Presented data (mean \pm s.e.m.) are representative results from one experiment with min. five mice/group; $P<0.05$ was considered significant; ${ }^{*}$ statistically different from CTRL, $P<0.05 ;^{*}$ statistically different from DSS, $P<0.05{ }^{\dagger}$ statistically different from CTRL $+\mathrm{HBO}_{2}, P<0.05$.

in a significant downregulation of CAT mRNA expression in the colonic mucosa, and the $\mathrm{HBO}_{2}$ treatment induced its upregulation in the spleen of DSS $+\mathrm{HBO}_{2}$ group of mice. These results were largely in accordance with our finding on enzymatic catalase activity that was decreased in all measured tissues in the DSS group and reversed to control values in the spleen of DSS $+\mathrm{HBO}_{2}$ group (Table 2), as well as with a previous study demonstrating decreased catalase activity in colonic tissue upon DSS treatment [53]. This is also in line with a study on skin transplanted $\mathrm{BALB} / \mathrm{c}$ mice where $\mathrm{HBO}_{2}$ treatment increased catalase, GPx, and SOD activity in the spleen [54]. Furthermore, upregulation of protein and mRNA catalase levels 14 days after $\mathrm{HBO}_{2}$ treatment, but not after 7 days, was also observed in the ulcer tissue of patients with diabetic foot, indicating a time-course for the effect of $\mathrm{HBO}_{2}$ to prevail [55].

We found that GPx1 mRNA level was upregulated in the colon of DSS treated mice, irrespective of the $\mathrm{HBO}_{2}$ treatment, and there were no significant differences in the GPx1 mRNA expression in MLN and spleen. In contrast to our findings on mRNA expression, colon GPx enzyme activity was slightly reduced in DSS $+\mathrm{HBO}_{2}$ group compared to other groups, which is consistent with previous results obtained in acetic acid induced colitis in rats receiving combined $\mathrm{HBO}_{2}$ and ozone treatment [56]. However, other reports indicate decreased GPx and SOD activity in the inflamed distal colon mucosa and the plasma of rats with acetic acid induced colitis, and $\mathrm{HBO}_{2}$ normalized GPx but not SOD activity in the colon [24]. The observed discrepancies in the results may be related to the differences in experimental models used among the studies. In addition, in our study $\mathrm{HBO}_{2}$ treatment induced enhanced GPx and SOD activity in the spleen of DSS mice which is in contrast to reduced SOD1 mRNA expression and might be explained by additional SOD2 and SOD3 function in regulation of antioxidative capacity. Although intracellular $\mathrm{H}_{2} \mathrm{O}_{2}$ and $\mathrm{ONOO}^{-}$levels were slightly increased during inflammation and $\mathrm{HBO}_{2}$ treatment in the MLN and $\mathrm{HBO}_{2}$ per se increased its level in spleen, impaired lymphocyte function was not observed.
Intensive research on the beneficial wound healing effects of $\mathrm{HBO}_{2}$ revealed its capacity to induce neovascularization, reduce oedema, decrease leukocyte adhesion, stimulate fibroblast expansion, and inhibit bacterial growth [14, 57]. Some of these processes are transcriptionally regulated by $H I F-1 \alpha$, namely, the vascular endothelial growth factor (VEGF) expression [58], regulatory T lymphocyte differentiation [59], and preservation of epithelial thigh junction integrity [60]. In addition, previous studies employing conditional deletion of epithelial HIF-1 $\alpha$ or pharmacologic activation of $H I F-1 \alpha$ in a murine model of colitis demonstrated a protective role for HIF-1 $\alpha$ in colitis [61]. It has also been shown that HIF-1 increases expression of barrier-protective genes (multidrug resistance gene-1, intestinal trefoil factor, CD73) [62], decreases TNF $\alpha$ mRNA expression [61], and enhances antimicrobial activity by transcribing beta-defensin 1 [63]. In the present study we found increased expression of HIF-1 $\alpha$ gene in inflamed colonic tissue, and $\mathrm{HBO}_{2}$ further increased its level. In the peripheral lymphoid organs $H I F-1 \alpha$ gene expression was changed (upregulated) by the inflammation while $\mathrm{HBO}_{2}$ treatment showed a tendency to reverse this increase. These data suggest involvement of different mechanisms controlling HIF-1 $\alpha$ gene expression at the site of inflammation (colon) and the peripheral lymphoid organs (MLN and spleen), responsible for the initiation of the immune response and the T/B-cell expansion and differentiation, respectively. We also demonstrated a strong positive correlation between HIF-1 $\alpha$ and GPx1 mRNA levels in the colon (Figure $4(\mathrm{~b})$ ). This is in line with in vitro studies where overexpressed $H I F-1 \alpha$ in colorectal cancer cells resulted in enhanced GPx1 expression through TGF$\beta \mathrm{RI} / \mathrm{Smad} 2 / \mathrm{ERK} 1 / 2 / H I F-1 \alpha$ signalling cascade, suggesting transcriptional regulation of GPx1 by HIF-1 $\alpha$ [64].

In the present study we found strong negative correlation between HIF-1 $\alpha$ and SOD1 mRNA expression. This is in accordance with a previous study showing that docosahexaenoic acid downregulates SOD1 gene transcription through an HRE-mediated mechanism (HRE, hypoxia-response element), involving HIF signalling in human cancer cells [65]; 


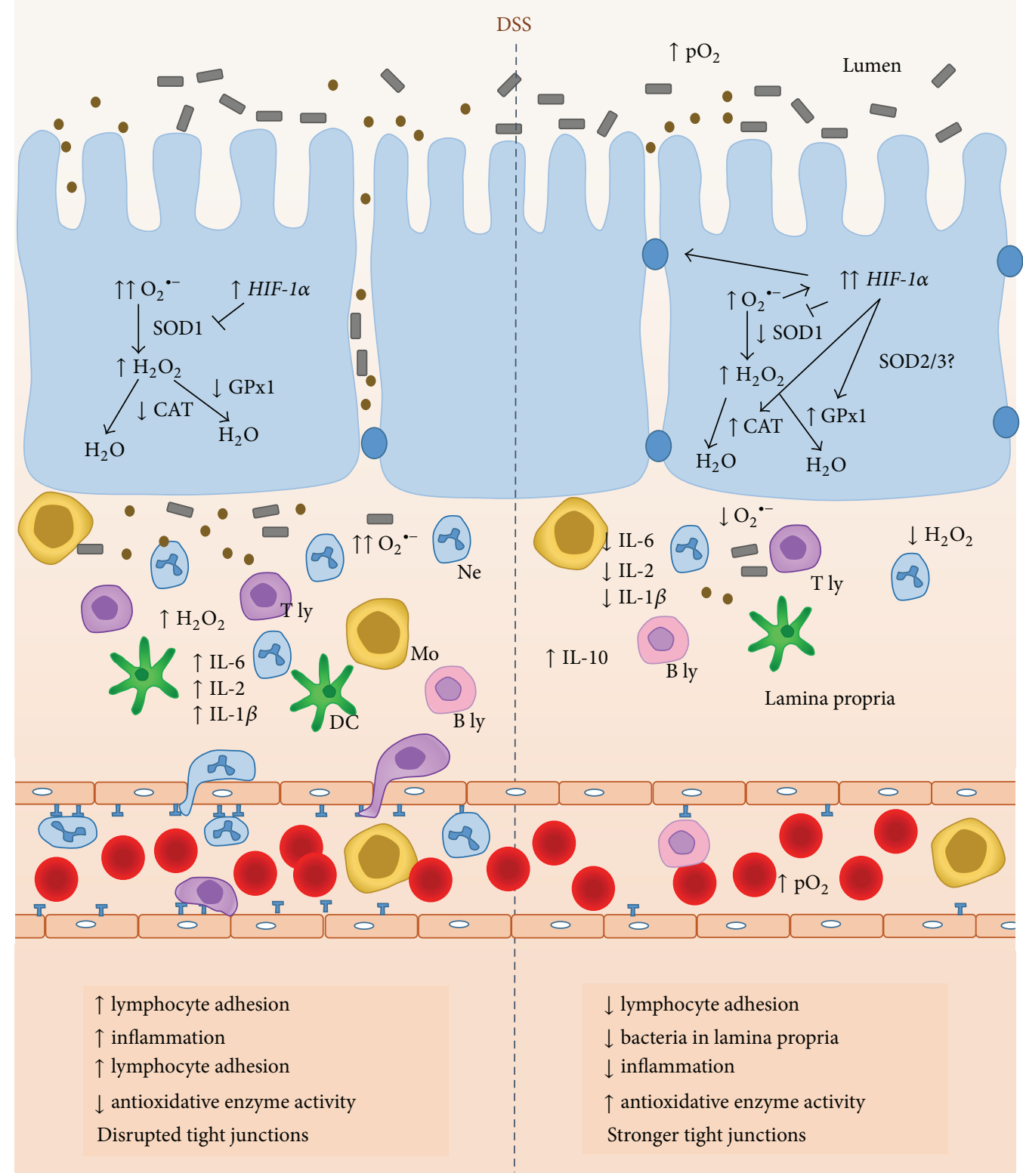

FIGURE 7: Proposed mechanisms mediating effects of $\mathrm{HBO}_{2}$ on the inflammation during DSS-induced colitis. Compared to untreated DSSinduced colitis (left of the vertical dotted line), high partial pressure of oxygen during $\mathrm{HBO}_{2}$ (right) activates HIF-1 $\alpha$ signaling which leads to higher CAT and GPXI mRNA expression resulting in reduced oxidative stress in the inflamed colonic mucosa. HIF-1 $\alpha$ mediated (negative) transcriptional regulation of proinflammatory cytokine IL-6 and reduced oxidative tissue injury leads to decreased neutrophil, monocyte, and lymphocyte adhesion and infiltration to the gut mucosa. In addition, $\mathrm{HBO}_{2}$ activates genes encoding for barrier-protection and genes responsible for improving tight junction integrity, all together resulting in reduced number of bacteria entering the lamina propria of gut mucosa. T ly, T lymphocyte; B ly, B lymphocyte; DC, dendritic cell; Ne, neutrophil; Mo, monocyte/macrophage; HIF-1 $\alpha$, hypoxia inducible factor 1 alpha; CAT, catalase; GPx1, glutathione peroxidase 1; SOD1, superoxide dismutase 1; $\mathrm{pO}_{2}$, partial $\mathrm{O}_{2}$ pressure; $\uparrow$, increased; $\downarrow$, decreased.

thus our results indicate similar mechanism involved in SOD1 control in the murine colon mucosa in vivo during colitis and $\mathrm{HBO}_{2}$.

Previous studies revealed that HIF-1 $\alpha$ mediated transcriptional regulation of different proinflammatory cytokines and growth factor genes are tissue and cell specific and include regulation trough alternative splicing, mRNA stability, and interactions with other transcription factors like NF- $\kappa \mathrm{B}$
[66-69]. In our study we found a strong correlation between $H I F-1 \alpha$ and $I L-6$ mRNA levels suggesting involvement of HIF- $1 \alpha$ in transcriptional regulation of IL-6 gene during colonic inflammation and $\mathrm{HBO}_{2}$.

In conclusion, our results confirmed that $\mathrm{HBO}_{2}$ exerts an anti-inflammatory effect on DSS-induced colitis in mice, and this effect at least involves HIF-1 $\alpha$ and antioxidative genes expression regulation (as outlined in Figure 7). However, 
further studies are necessary to identify the cells that may contribute to or are influenced by the effects upon $\mathrm{HBO}_{2}$ treatment.

$\begin{array}{ll}\text { Abbreviations } \\ \text { CAT: } & \text { Catalase } \\ \text { CTRL: } & \text { Control } \\ \text { DAI: } & \text { Disease activity index } \\ \text { DCF DA: } & \text { Dichlorofluorescein acetate } \\ \text { DSS: } & \text { Dextran sodium sulfate } \\ \text { GPxl: } & \text { Glutathione peroxidase } 1 \\ \text { HBO } & \text { Hyperbaric oxygen } \\ \text { HRE: } & \text { Hypoxia-response element } \\ \text { HIF-1 }: & \text { Hypoxia inducible factor-1 alpha } \\ \text { IBD: } & \text { Inflammatory bowel disease } \\ \text { MFI: } & \text { Median fluorescence intensity } \\ \text { MLN: } & \text { Mesenteric lymph node } \\ \mathrm{O}_{2}{ }^{-}: & \text {Superoxide radical } \\ \text { ONOO } & \text { Peroxynitrite } \\ \text { PMA: } & \text { Phorbol 12-myristate 13-acetate } \\ \text { RNS: } & \text { Reactive nitrogen species } \\ \text { ROS: } & \text { Reactive oxygen species } \\ \text { s.e.m.: } & \text { Standard error mean } \\ \text { SOD1: } & \text { Superoxide dismutase 1 } \\ \text { TCR: } & \text { T cell receptor } \\ \text { Treg: } & \text { T regulatory lymphocyte } \\ \text { VEGF: } & \text { Vascular endothelial growth factor. } \\ & \\ & \end{array}$

\section{Competing Interests}

The authors declare no conflict of interests.

\section{Authors' Contributions}

Martina Mihalj and Sanja Novak conceived and designed the study. Sanja Novak, Martina Mihalj, Rosemary Vukovic, Zoltán Kellermayer, and Anita Cosic performed the experiments. Maja Tolusic Levak performed pathohistological evaluation and analysis and wrote the paper. Rosemary Vukovic, Sanja Novak, Martina Mihalj, Péter Balogh, and Ines Drenjancevic contributed to data analysis and interpretation. Sanja Novak wrote the first draft of the paper. Martina Mihalj, Péter Balogh, and Zoltán Kellermayer critically revised the paper, and all authors read and approved its final version.

\section{Acknowledgments}

This work was supported by the grant of the Croatian Ministry of Science, Education and Sports to ID (219-21601332034) and FC (219-0000000-0328) and the grant of Faculty of Medicine University of Osijek to MM (\#VIF2015 -MEFOS-8). Authors thank Dr. Hrvoje Mihalj for language editing of the paper.

\section{References}

[1] P. Goyette, G. Boucher, D. Mallon et al., "High-density mapping of the MHC identifies a shared role for HLA-DRB1*01:03 in inflammatory bowel diseases and heterozygous advantage in ulcerative colitis," Nature Genetics, vol. 47, no. 2, pp. 172-179, 2015.

[2] J. Satsangi, M. S. Silverberg, S. Vermeire, and J.-F. Colombel, "The Montreal classification of inflammatory bowel disease: controversies, consensus, and implications," Gut, vol. 55, no. 6, pp. 749-753, 2006.

[3] R. A. Risquesa, P. S. Rabinovitch, and T. A. Brentnall, "Cancer surveillance in inflammatory bowel disease: new molecular approaches," Current Opinion in Gastroenterology, vol. 22, no. 4, pp. 382-390, 2006.

[4] C. Nathan and A. Cunningham-Bussel, "Beyond oxidative stress: an immunologist's guide to reactive oxygen species," Nature Reviews Immunology, vol. 13, no. 5, pp. 349-361, 2013.

[5] H. J. Lee, E. S. Jung, J. H. Lee et al., "Long-term clinical outcomes and factors predictive of relapse after 5-aminosalicylate or sulfasalazine therapy in patients with mild-to-moderate ulcerative colitis," Hepato-Gastroenterology, vol. 59, no. 117, pp. 1415-1420, 2012.

[6] W. J. Sandborn, B. G. Feagan, and G. R. Lichtenstein, "Medical management of mild to moderate Crohn's disease: evidencebased treatment algorithms for induction and maintenance of remission," Alimentary Pharmacology \& Therapeutics, vol. 26, no. 7, pp. 987-1003, 2007.

[7] L. R. Sutherland, G. R. May, and E. A. Shaffer, "Sulfasalazine revisited: a meta-analysis of 5-aminosalicylic acid in the treatment of ulcerative colitis," Annals of Internal Medicine, vol. 118, no. 7, pp. 540-549, 1993.

[8] A. Eskes, H. Vermeulen, C. Lucas, and D. T. Ubbink, "Hyperbaric oxygen therapy for treating acute surgical and traumatic wounds," The Cochrane Database of Systematic Reviews, no. 12, Article ID CD008059, 2013.

[9] V. G. Sunkari, F. Lind, I. R. Botusan et al., "Hyperbaric oxygen therapy activates hypoxia-inducible factor 1 (HIF-1), which contributes to improved wound healing in diabetic mice," Wound Repair and Regeneration, vol. 23, no. 1, pp. 98-103, 2015.

[10] B. Tuk, M. Tong, E. M. G. Fijneman, and J. W. Van Neck, "Hyperbaric oxygen therapy to treat diabetes impaired wound healing in rats," PLoS ONE, vol. 9, no. 10, Article ID e108533, 2014.

[11] T. Ueno, T. Omi, E. Uchida, H. Yokota, and S. Kawana, "Evaluation of hyperbaric oxygen therapy for chronic wounds," Journal of Nippon Medical School, vol. 81, no. 1, pp. 4-11, 2014.

[12] I. Drenjancevic, A. Kibel, D. Kibel, V. Seric, and A. Cosic, "Blood pressure, acid-base and blood gas status and indicators of oxidative stress in healthy male rats exposed to acute hyperbaric oxygenation," Undersea and Hyperbaric Medicine, vol. 40, no. 4, pp. 319-328, 2013.

[13] E. M. Camporesi and G. Bosco, "Mechanisms of action of hyperbaric oxygen therapy," Undersea and Hyperbaric Medicine, vol. 41, no. 3, pp. 247-252, 2014.

[14] S. R. Thom, "Oxidative stress is fundamental to hyperbaric oxygen therapy," Journal of Applied Physiology, vol. 106, no. 3, pp. 988-995, 2009.

[15] J. E. Ziello, I. S. Jovin, and Y. Huang, "Hypoxia-Inducible Factor (HIF)-1 regulatory pathway and its potential for therapeutic intervention in malignancy and ischemia," The Yale Journal of Biology and Medicine, vol. 80, no. 2, pp. 51-60, 2007.

[16] E. T. Clambey, E. N. McNamee, J. A. Westrich et al., "Hypoxiainducible factor-1 alpha-dependent induction of FoxP3 drives regulatory $\mathrm{T}$-cell abundance and function during inflammatory 
hypoxia of the mucosa," Proceedings of the National Academy of Sciences of the United States of America, vol. 109, no. 41, pp. E2784-E2793, 2012.

[17] J. Yao, C. Wei, J.-Y. Wang, R. Zhang, Y.-X. Li, and L.-S. Wang, "Effect of resveratrol on Treg/Th17 signaling and ulcerative colitis treatment in mice," World Journal of Gastroenterology, vol. 21, no. 21, pp. 6572-6581, 2015.

[18] K. M. Comerford, T. J. Wallace, J. Karhausen, N. A. Louis, M. C. Montalto, and S. P. Colgan, "Hypoxia-inducible factor1-dependent regulation of the multidrug resistance (MDR1) gene," Cancer Research, vol. 62, no. 12, pp. 3387-3394, 2002.

[19] G. T. Furuta, J. R. Turner, C. T. Taylor et al., "Hypoxia-inducible factor 1-dependent induction of intestinal trefoil factor protects barrier function during hypoxia," The Journal of Experimental Medicine, vol. 193, no. 9, pp. 1027-1034, 2001.

[20] N. A. Louis, K. E. Hamilton, G. Canny, L. L. Shekels, S. B. Ho, and S. P. Colgan, "Selective induction of mucin-3 by hypoxia in intestinal epithelia," Journal of Cellular Biochemistry, vol. 99, no. 6, pp. 1616-1627, 2006.

[21] N. S. Chandel, D. S. McClintock, C. E. Feliciano et al., "Reactive oxygen species generated at mitochondrial Complex III stabilize hypoxia-inducible factor- $1 \alpha$ during hypoxia: a mechanism of $\mathrm{O}_{2}$ sensing," The Journal of Biological Chemistry, vol. 275, no. 33, pp. 25130-25138, 2000.

[22] L. Lih-Brody, S. R. Powell, K. P. Collier et al., "Increased oxidative stress and decreased antioxidant defenses in mucosa of inflammatory bowel disease," Digestive Diseases and Sciences, vol. 41, no. 10, pp. 2078-2086, 1996.

[23] R. Ramonaite, J. Skieceviciene, G. Kiudelis et al., "Influence of NADPH oxidase on inflammatory response in primary intestinal epithelial cells in patients with ulcerative colitis," $B M C$ Gastroenterology, vol. 13, article 159, 2013.

[24] B. Gulec, M. Yasar, S. Yildiz et al., "Effect of hyperbaric oxygen on experimental acute distal colitis," Physiological Research, vol. 53, no. 5, pp. 493-499, 2004.

[25] E. Koçak, S. Köklü, E. Akbal et al., "NaOH-induced Crohn's colitis in rats: a novel experimental model," Digestive Diseases and Sciences, vol. 56, no. 10, pp. 2833-2837, 2011.

[26] I. Okayasu, S. Hatakeyama, M. Yamada, T. Ohkusa, Y. Inagaki, and R. Nakaya, "A novel method in the induction of reliable experimental acute and chronic ulcerative colitis in mice," Gastroenterology, vol. 98, no. 3, pp. 694-702, 1990.

[27] D. A. Rossignol, "Hyperbaric oxygen treatment for inflammatory bowel disease: a systematic review and analysis," Medical Gas Research, vol. 2, no. 1, article 6, 2012.

[28] T. Bessissow, B. Lemmens, M. Ferrante et al., "Prognostic value of serologic and histologic markers on clinical relapse in ulcerative colitis patients with mucosal healing," The American Journal of Gastroenterology, vol. 107, no. 11, pp. 1684-1692, 2012.

[29] E. Viennois, F. Chen, H. Laroui, M. T. Baker, and D. Merlin, "Dextran sodium sulfate inhibits the activities of both polymerase and reverse transcriptase: lithium chloride purification, a rapid and efficient technique to purify RNA," BMC Research Notes, vol. 6, no. 1, article 360, 2013.

[30] J. B. Jeong, Y. K. Shin, and S.-H. Lee, "Anti-inflammatory activity of patchouli alcohol in RAW264.7 and HT-29 cells," Food and Chemical Toxicology, vol. 55, pp. 229-233, 2013.

[31] H. Aebi, "Catalase in vitro," Methods in Enzymology, vol. 105, pp. 121-126, 1984.

[32] A. Wendel, "Glutathione peroxidase," in Enzymatic Basis of Detoxication, W. B. Jakoby, Ed., chapter 16, pp. 333-353, Academic Press, New York, NY, USA, 1980.
[33] L. Flohe and F. Otting, "Superoxide dismutase assays," Methods in Enzymology, vol. 105, pp. 93-104, 1984.

[34] P. S. Dulai, M. W. Gleeson, D. Taylor, S. D. Holubar, J. C. Buckey, and C. A. Siegel, "Systematic review: the safety and efficacy of hyperbaric oxygen therapy for inflammatory bowel disease," Alimentary Pharmacology \& Therapeutics, vol. 39, no. 11, pp. 1266-1275, 2014.

[35] M.-F. Chen, H.-M. Chen, S. W. N. Ueng, and M.-H. Shyr, "Hyperbaric oxygen pretreatment attenuates hepatic reperfusion injury," Liver, vol. 18, no. 2, pp. 110-116, 1998.

[36] C. Luongo, F. Imperatore, S. Cuzzocrea et al., "Effects of hyperbaric oxygen exposure on a zymosan-induced shock model," Critical Care Medicine, vol. 26, no. 12, pp. 1972-1976, 1998.

[37] Y. Sakashita, E. Hiyama, Y. Imamura et al., "Generation of pro-inflammatory and anti-inflammatory cytokines in the gut in zymosan-induced peritonitis," Hiroshima Journal of Medical Sciences, vol. 49, no. 1, pp. 43-48, 2000.

[38] D. Erdmann, A. C. Roth, J. Hussmann et al., "Skin allograft rejection and hyperbaric oxygen treatment in immunehistoincompatible mice," Undersea \& Hyperbaric Medicine, vol. 22, no. 4, pp. 395-399, 1995.

[39] J. F. Hansbrough, J. G. Piacentine, and B. Eiseman, "Immunosuppression by hyperbaric oxygen," Surgery, vol. 87, no. 6, pp. 662-667, 1980.

[40] K. Saito, Y. Tanaka, T. Ota, S. Eto, and U. Yamashita, "Suppressive effect of hyperbaric oxygenation on immune responses of normal and autoimmune mice," Clinical and Experimental Immunology, vol. 86, no. 2, pp. 322-327, 1991.

[41] X. Xu, H. Yi, M. Kato et al., "Differential sensitivities to hyperbaric oxygen of lymphocyte subpopulations of normal and autoimmune mice," Immunology Letters, vol. 59, no. 2, pp. 79-84, 1997.

[42] B. Kudchodkar, H. Jones, J. Simecka, and L. Dory, "Hyperbaric oxygen treatment attenuates the pro-inflammatory and immune responses in apolipoprotein E knockout mice," Clinical Immunology, vol. 128, no. 3, pp. 435-441, 2008.

[43] L. J. Hall, E. Faivre, A. Quinlan, F. Shanahan, K. Nally, and S. Melgar, "Induction and activation of adaptive immune populations during acute and chronic phases of a murine model of experimental colitis," Digestive Diseases and Sciences, vol. 56, no. 1, pp. 79-89, 2011.

[44] A. Schippers, M. Muschaweck, T. Clahsen et al., " $\beta 7$-Integrin exacerbates experimental DSS-induced colitis in mice by directing inflammatory monocytes into the colon," Mucosal Immunology, vol. 9, pp. 527-538, 2016.

[45] A. K. Lee, R. B. Hester, J. H. Coggin, and S. F. Gottlieb, "Increased oxygen tensions modulate the cellular composition of the adaptive immune system in BALB/c mice," Cancer Biotherapy, vol. 8, no. 3, pp. 241-252, 1993.

[46] J. E. Qualls, A. M. Kaplan, N. Van Rooijen, and D. A. Cohen, "Suppression of experimental colitis by intestinal mononuclear phagocytes," Journal of Leukocyte Biology, vol. 80, no. 4, pp. 802815, 2006.

[47] G. Butler, J. C. Michaels, N. Al-Waili et al., "Therapeutic effect of hyperbaric oxygen in psoriasis vulgaris: two case reports and a review of the literature," Journal of Medical Case Reports, vol. 3, article 7023, 2009.

[48] C.-C. Niu, S.-S. Lin, L.-J. Yuan et al., "Hyperbaric oxygen treatment suppresses MAPK signaling and mitochondrial apoptotic pathway in degenerated human intervertebral disc cells," Journal of Orthopaedic Research, vol. 31, no. 2, pp. 204-209, 2013. 
[49] G. Weisz, A. Lavy, Y. Adir et al., "Modification of in vivo and in vitro TNF- $\alpha$, IL-1, and IL- 6 secretion by circulating monocytes during hyperbaric oxygen treatment in patients with perianal Crohn's disease," Journal of Clinical Immunology, vol. 17, no. 2, pp. 154-159, 1997.

[50] M. Schieber and N. S. Chandel, "ROS function in redox signaling and oxidative stress," Current Biology, vol. 24, no. 10, pp. R453-R462, 2014.

[51] M. Perše and A. Cerar, "Dextran sodium sulphate colitis mouse model: traps and tricks," Journal of Biomedicine \& Biotechnology, vol. 2012, Article ID 718617, 3 pages, 2012.

[52] M. Hultqvist, L. M. Olsson, K. A. Gelderman, and R. Holmdahl, "The protective role of ROS in autoimmune disease," Trends in Immunology, vol. 30, no. 5, pp. 201-208, 2009.

[53] A. K. Pandurangan, N. Mohebali, M. E. Norhaizan, and C. Y. Looi, "Gallic acid attenuates dextran sulfate sodium-induced experimental colitis in BALB/c mice," Drug Design, Development and Therapy, vol. 9, pp. 3923-3934, 2015.

[54] Y. Yu, W. Tian, H. Zhang, and X. Chen, "Effects of hyperbaric oxygen and cyclosporin $\mathrm{A}$ on the levels of active oxygens and nitric oxide in spleens of skin transplanted mice," Chinese Journal of Pathophysiology, vol. 16, pp. 1286-1288, 2000.

[55] L. Ma, P. Li, Z. Shi, T. Hou, X. Chen, and J. Du, "A prospective, randomized, controlled study of hyperbaric oxygen therapy: effects on healing and oxidative stress of ulcer tissue in patients with a diabetic foot ulcer," Ostomy/Wound Management, vol. 59, no. 3, pp. 18-24, 2013.

[56] O. Altinel, S. Demirbas, E. Cakir et al., "Comparison of hyperbaric oxygen and medical ozone therapies in a rat model of experimental distal colitis," Scandinavian Journal of Clinical and Laboratory Investigation, vol. 71, no. 3, pp. 185-192, 2011.

[57] A. L. Gill and C. N. A. Bell, "Hyperbaric oxygen: its uses, mechanisms of action and outcomes," Monthly Journal of the Association of Physicians, vol. 97, no. 7, pp. 385-395, 2004.

[58] J. A. Forsythe, B.-H. Jiang, N. V. Iyer et al., "Activation of vascular endothelial growth factor gene transcription by hypoxiainducible factor 1," Molecular and Cellular Biology, vol. 16, no. 9, pp. 4604-4613, 1996.

[59] K. Flück, G. Breves, J. Fandrey, and S. Winning, "Hypoxiainducible factor 1 in dendritic cells is crucial for the activation of protective regulatory T cells in murine colitis," Mucosal Immunology, vol. 9, no. 2, pp. 379-390, 2016.

[60] B. J. Saeedi, D. J. Kao, D. A. Kitzenberg et al., "HIF-dependent regulation of claudin-1 is central to intestinal epithelial tight junction integrity," Molecular Biology of the Cell, vol. 26, no. 12, pp. 2252-2262, 2015.

[61] A. Robinson, S. Keely, J. Karhausen, M. E. Gerich, G. T. Furuta, and S. P. Colgan, "Mucosal protection by hypoxia-inducible factor prolyl hydroxylase inhibition," Gastroenterology, vol. 134, no. 1, pp. 145-155, 2008.

[62] J. Karhausen, G. T. Furuta, J. E. Tomaszewski, R. S. Johnson, S. P. Colgan, and V. H. Haase, "Epithelial hypoxia-inducible factor1 is protective in murine experimental colitis," The Journal of Clinical Investigation, vol. 114, no. 8, pp. 1098-1106, 2004.

[63] C. J. Kelly, L. E. Glover, E. L. Campbell et al., "Fundamental role for HIF- $1 \alpha$ in constitutive expression of human $\beta$ defensin-1," Mucosal Immunology, vol. 6, no. 6, pp. 1110-1118, 2013.

[64] Y. Huang, W. Fang, Y. Wang, W. Yang, and B. Xiong, “Transforming growth factor- $\beta 1$ induces glutathione peroxidase- 1 and protects from $\mathrm{H}_{2} \mathrm{O}_{2}$-induced cell death in colon cancer cells via the Smad2/ERK1/2/HIF-1 $\alpha$ pathway," International Journal of Molecular Medicine, vol. 29, no. 5, pp. 906-912, 2012.
[65] E. R. Tuller, C. T. Beavers, J. R. Lou, M. A. Ihnat, D. M. Benbrook, and W.-Q. Ding, "Docosahexaenoic acid inhibits superoxide dismutase 1 gene transcription in human cancer cells: the involvement of peroxisome proliferator-activated receptor $\alpha$ and hypoxia-inducible factor- $2 \alpha$ signaling," Molecular Pharmacology, vol. 76, no. 3, pp. 588-595, 2009.

[66] N. Hatano, Y. Itoh, H. Suzuki et al., "Hypoxia-inducible factor$1 \alpha($ HIFl $\alpha)$ switches on transient receptor potential ankyrin repeat 1 (TRPA1) gene expression via a hypoxia response element-like motif to modulate cytokine release," The Journal of Biological Chemistry, vol. 287, no. 38, pp. 31962-31972, 2012.

[67] H.-J. Jeong, H.-S. Chung, B.-R. Lee et al., "Expression of proinflammatory cytokines via HIF- $1 \alpha$ and NF- $\kappa \beta$ activation on desferrioxamine-stimulated HMC-1 cells," Biochemical and Biophysical Research Communications, vol. 306, no. 4, pp. 805811, 2003.

[68] H.-J. Jeong, S.-H. Hong, R.-K. Park, T. Shin, N.-H. An, and H.M. Kim, "Hypoxia-induced IL-6 production is associated with activation of MAP kinase, HIF-1, and NF- $\kappa$ B on HEI-OC1 cells," Hearing Research, vol. 207, no. 1-2, pp. 59-67, 2005.

[69] M. A. Rahat, H. Bitterman, and N. Lahat, "Molecular mechanisms regulating macrophage response to hypoxia," Frontiers in Immunology, vol. 2, article 45, 2011. 


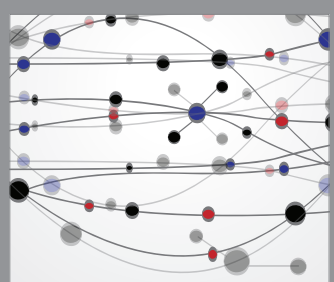

The Scientific World Journal
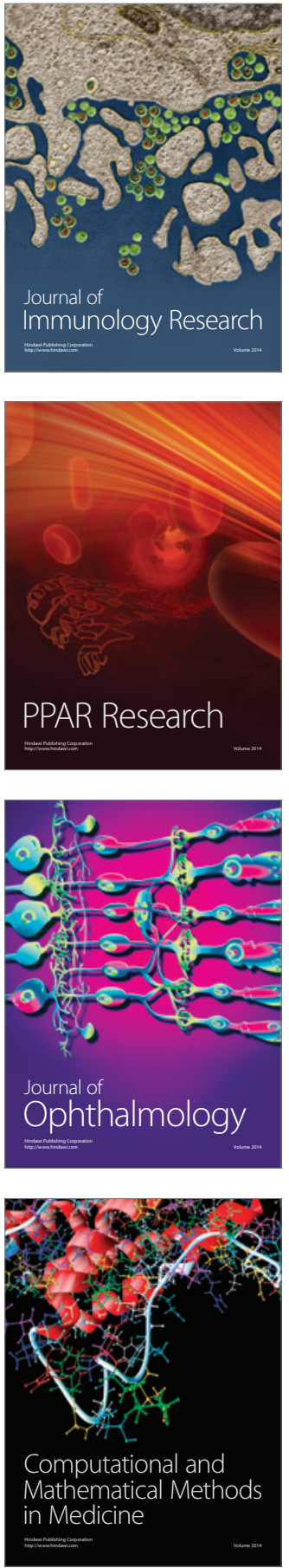

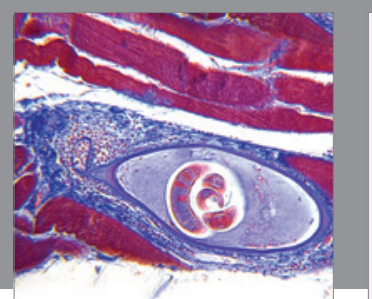

Gastroenterology Research and Practice

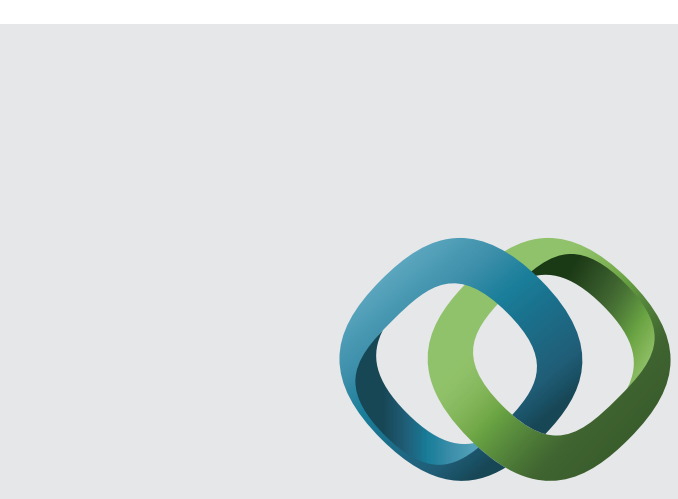

\section{Hindawi}

Submit your manuscripts at

http://www.hindawi.com
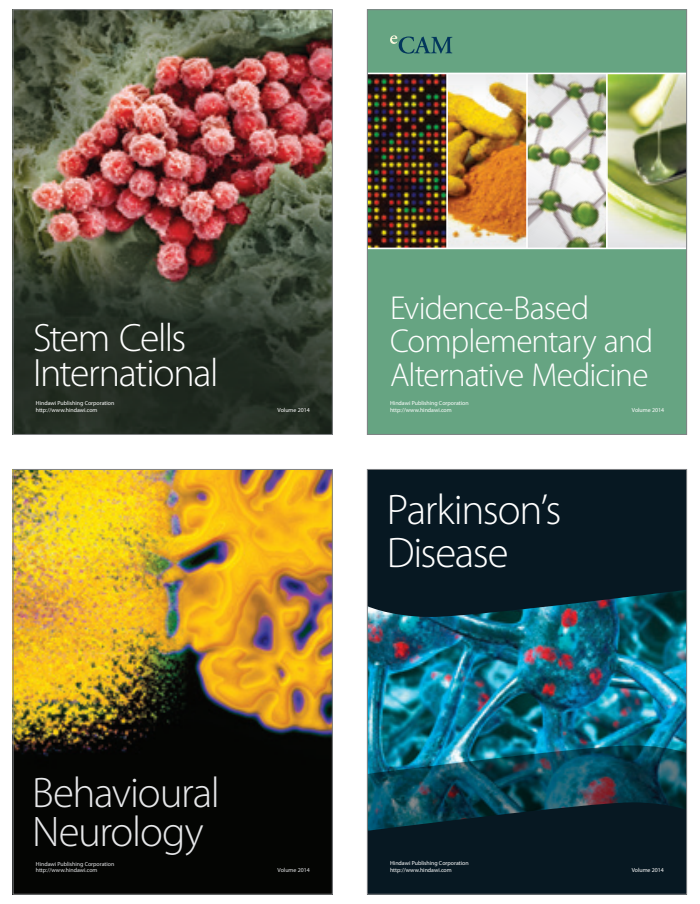
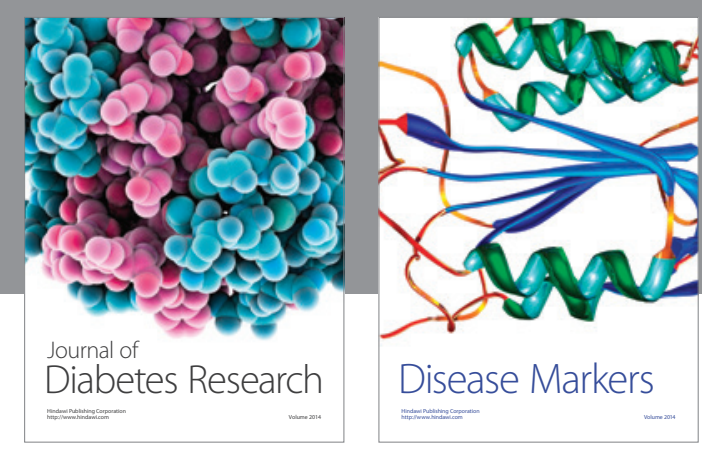

Disease Markers
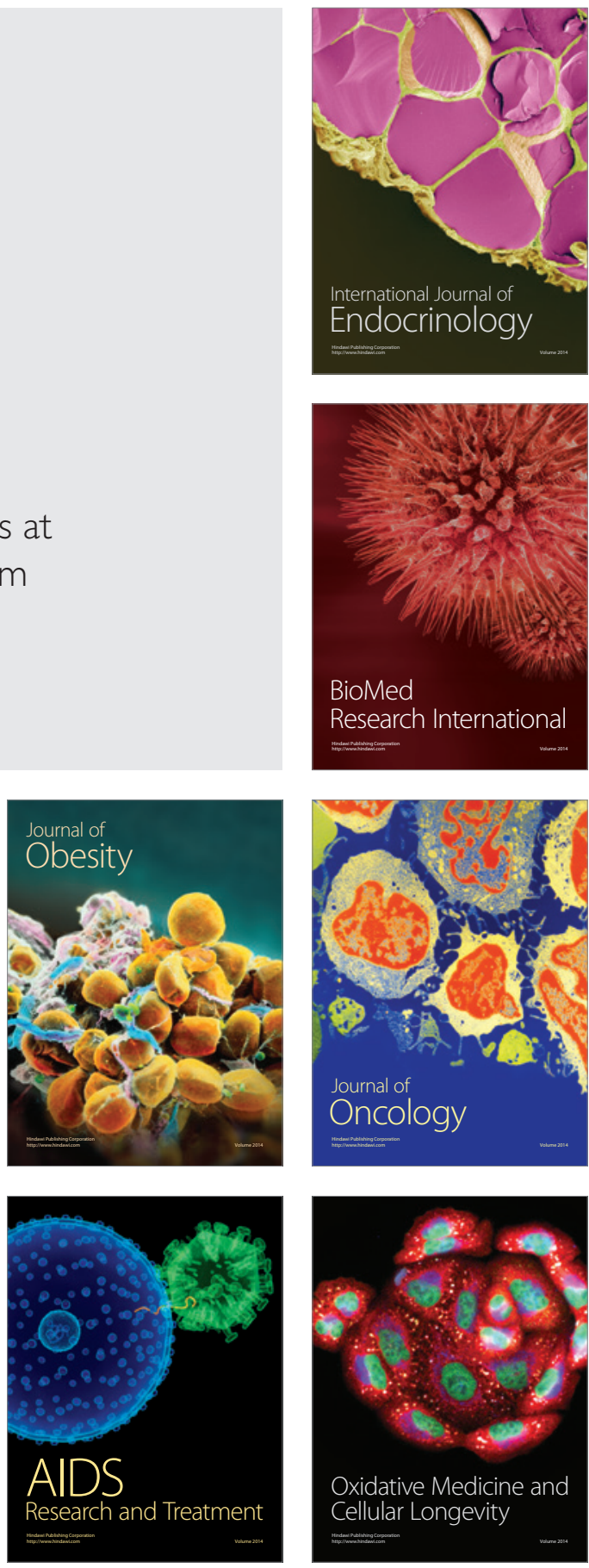